\title{
The Economic And Institutional Determinants of Foreign Direct INVESTMENTS
}

\author{
Maxime Delabarre
}

December 27, 2020

\begin{abstract}
This paper aims to investigate the economic and institutional determinants of Foreign Direct Investment in the world post-2000. To this end, I analyze the inwards stocks of FDIs using unilateral and bilateral data. Based on the UNCTAD database, I also study the impact of Bilateral Investment Treaties on the inflow of FDIs. Main results provide evidence supporting the idea that treaties increase the inflows of FDIs in the years following their signature. However, regulations aimed at increasing the protection of property rights have a larger effect on the attractiveness for investors. This paper does not find robust evidence demonstrating that political stability and corruption level have significant effects. More, I demonstrate that an increase of tariffs in the host country results in an increase of FDIs, supposedly due to relocation processes.
\end{abstract}




\section{Contents}

1 Introduction 4

2 Literature Review 5

2.1 FDIs and Growth $\ldots \ldots \ldots \ldots \ldots \ldots \ldots \ldots \ldots \ldots \ldots \ldots \ldots \ldots \ldots \ldots$

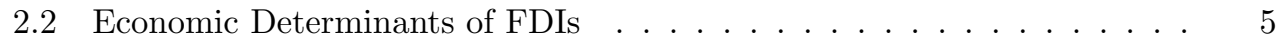

2.3 Institutional Determinants of FDIs . . . . . . . . . . . . . 6

2.4 The Question of Corruption . . . . . . . . . . . . . . 7

3 Data $\quad 8$

4 Methodology $\quad 8$

4.1 Economic Determinants . . . . . . . . . . . . . . . . . . . . . 9

4.2 Institutional Determinants . . . . . . . . . . . . . . . . . . . . 10

4.3 Justification for Model Specifications and Robustness . . . . . . . . . . . 11

5 Results and Discussion $\quad 12$

5.1 Summary of Findings . . . . . . . . . . . . . . . . . . 12

5.2 Limitations and Future Research . . . . . . . . . . . . . . . . . . . 14

6 Conclusion $\quad 15$

$\begin{array}{llr}7 & \text { References } & 16\end{array}$

8 Appendix 22 


\section{List of Tables}

1 Economic determinants - Main results . . . . . . . . . . . . . 12

2 Institutional determinants - Main results . . . . . . . . . . . . . . 13

3 Data Description . . . . . . . . . . . . . . . . . 23

4 Countries used in unilateral models . . . . . . . . . . . . . . . . 26

5 Countries used in bilateral models . . . . . . . . . . . . . . . 27

6 Correlations Results ...................... 28

7 Economic Determinants . . . . . . . . . . . . . . . 29

8 Economic Determinants with Fixed Effects . . . . . . . . . . . . 30

9 Economic Determinants - Gravity Model . . . . . . . . . . . . . . . . 31

10 Economic Determinants - Gravity Model with Fixed Effects . . . . . . . 32

11 Institutional Determinants . . . . . . . . . . . . . . . . . 33

12 Institutional Determinants with Fixed Effects . . . . . . . . . . . . . . 34

13 Institutional Determinants - Gravity Model . . . . . . . . . . . . . . . . 35

14 Institutional Determinants - Gravity Model with Fixed Effects . . . . . 36 


\section{Introduction}

Explaining the determinants of Foreign Direct Investments (FDIs) is subject to abundant theoretical literature, notably on the question of the response of multinational companies (MNCs) to governance (Bellos and Subasat 2012). Quality of domestic institutions has been for almost 20 years now the tool used to explain cross-country differences in growth rate (Acemoglu, Johnson, and Robinson 2005; IMF 2020), and the same theory has been transposed to FDIs. Indeed, FDIs constitute a large share of capital formation, especially in developing countries (UNCTAD 2020) which have become targets for investments due to high profitability potentials (Fornes and Butt-Philip 2011; Paul 2016; Welsh, Alon, and Falbe 2006). Recent development stories have been explained by the importance of FDIs (Crespo and Fontoura 2007; Paul and Singh 2017) through the fact that they bring new technologies, generate employment opportunities (Alfaro et al. 2004; Giroud and Scott-Kennel 2009; C. Ho and Rashid 2011; Jadhav 2012; Smarzynska Javorcik 2004), and enhance tax revenues which can, in turn, be used by the government (Adhikary 2011; Azam 2010; Bhavan, Xu, and Zhong 2011). FDIs are therefore considered as a significant determinant of growth in developing markets, explaining why economies are keen to know how to increase substantially their ability to attract FDIs (Hasli, Ho, and Ibrahim 2015; Hayami et al. 2005; Noorbakhsh, Paloni, and Youssef 2001). All of this brought the spotlight on the international investment phenomenon and its relationship with institutions (Bénassy-Quéré, Coupet, and Mayer 2007). Specifically, rule of law and protection of property rights are particularly studied.

At first sight, good governance is likely to be positively correlated with the amount of FDIs a country will receive. Relying on the work of Kaufmann et al. (1999), governance is considered as the set of traditions and institutions through which authority is exercised. Good governance constitutes, according to Li (2005), "an independent judiciary and legislation, fair and transparent laws with impartial enforcement, reliable public financial information, and high public trust".

When considering the quality of institutions, several reasons can explain its hypothetical positive link with FDI inflows (Bénassy-Quéré, Coupet, and Mayer 2007). First, good infrastructures raise productivity. Reversely, bad governance will create additional costs. This has been particularly demonstrated in the case of corruption (Wei 2000). Finally, MNCs investing in badly governed countries run the risk of uncertainty, particularly through the potential expropriations they could be subjected to. Still, empirical examination of the impact of institutional and economic determinants of FDIs is relatively limited in the literature, especially on the global scale. This paper proposes to contribute to the debate by studying up to 139 countries using both a standard panel model containing total inwards FDIs stocks per year (between 2000 and 2018) and a panel data gravity model, relying on bilateral relationships (between 2000 and 2012).

The remainder of the paper is organized as follows: Section 2 provides a short literature review while Section 3 and 4 describe the data and methodologies used. Finally, Section 5 discusses the results. 


\section{Literature Review}

A lot of studies have recently focused on the institutional determinants of Foreign Direct Investment (Kumari and Sharma 2017; Saini and Singhania 2018; Demirbag, McGuinness, and Altay 2010; Frenkel, Funke, and Stadtmann 2004; Moosa and Cardak 2006) but mainly focus on a limited number of countries each time. Despite this fact, Cevis and Camurdan demonstrated that openness and systemic reforms in emerging markets allowed them to attract more FDI. As Kemp (1969) argues, FDIs tend to be located in countries where investors can obtain more profit. Henceforth, he argues that lower production costs and exchange rate risks favored FDIs. Relying on the work of Kindleberger (1969), Nayak and Choudhury (2014) demonstrated how capitals will allocate in places where the return on investment is higher when there is no uncertainty. If the relationship between FDI and growth is sometimes contested (2.1), several scholars have focused their studies on the determinants of FDI inflows, from the economic (2.2) and institutional (2.3) standpoints. As corruption is the heart of some current debates, it will be addressed separately (2.4).

\section{$2.1 \quad$ FDIs and Growth}

The relationship between FDI inflows and growth has been widely studied - and contested - in the literature over the past few years. Overall, it seems that countries are convinced of the positive impact of inflows on growth as they all progressively lifted all restrictions imposed on capital flows (UNCTAD 2020), a huge effort as FDIs represent $60 \%$ of private capital flows (Alfaro et al. 2004).

However, even though some authors agree with the positive impact of FDI (Mello 1997; Choong et al. 2010), others did not find robust evidence (Irandoust 2001) when they do not find a negative effect (Moran 1998). Overall, Cohen and Levinthal (1990) first described how the absorptive capacity of a country played an important role in its ability to grow with FDI. As such, institutional determinants seem to matter not only on the ability of a country to attract FDI inflows but also on its ability to benefit from it (Azman-Saini, Baharumshah, and Law 2010).

\subsection{Economic Determinants of FDIs}

On the economic side, several studies argued that the economic stability of the host country is the key. Exchange rates and inflations are the usual proxies for macroeconomic stability (Froot and Stein 1991). Particularly, as inflation makes the cost of assets more expensive in the host country for a foreign company, it is usually perceived as a negative driver. The same constatation goes for the exchange rate, considered as an obstacle to entry.

More, the openness of countries has been frequently studied using the trade share (as a percentage of GDP) (Cleeve 2008; Mhlanga, Blalock, and Christy 2010; Bhavan, $\mathrm{Xu}$, and Zhong 2011), showing a positive correlation between openness and FDIs.

As such, one could expect tariffs and other trade barriers to be negatively correlated 
with FDI. This must be balanced with the fact that if companies are experiencing high trade barriers with a market they want to operate in, they could be tempted to invest or relocate it to avoid those costs. In a study published in 2020, Ghodsi demonstrated how FDIs were motivated by "tariff jumping" motives (Ghodsi 2020). He argues that both tariffs and technical trade barriers are positively correlated with FDI inflows in European countries. As long as companies can relatively freely relocate it seems hence plausible to see a positive correlation between costs of trade and FDIs.

Finally, Dunnin (2003) studied the determinants of FDI in developing countries and argued that MCNs shifted from resource to efficiency-seeking. Henceforth, the determinants affecting only the profitability of the company, such as labor costs and infrastructures, are more and more losing interest with regards to governance and property rights (Loree and Guisinger 1995; Noorbakhsh, Paloni, and Youssef 2001; Addison and Heshmati 2003; Becchetti and Hasan 2005).

\subsection{Institutional Determinants of FDIs}

Institutional determinants have been widely studied as well. As soon as 1992, Wheeler and Mody operated a Principal Component Analysis of risk factors on US foreign investments, showing no tangible effect of good institutions (Wheeler and Mody 1992). However, this view has been contested as it seems plausible to see investors worry about the institutional determinants of their investment. International lawyers are well aware of this fact as the mere aim of international investment law is to protect investors against the uncertainty of investing in unstable countries. For centuries the minimum standard of protection has prevailed, ensuring that foreign investors are treated according to internationally recognized judicial standards.

Globerman and Shapiro (2003) studied the prevailing view according to which good governance is positively linked with FDI inflows. More specifically, they demonstrated how institutional factors such as transparency, government efficiency, and common law origin are positive drivers for a country to receive US FDIs. They next show how the amount of investment is positively correlated with good governance and infrastructure. Economists vested in the political economy of development studies the impact of economic and political institutions on FDIs. They argue that regulatory quality and lower corruption are, among others, determinants of FDIs (Acemoglu, Johnson, and Robinson 2005). Henceforth, lots of studies have been conducted linking institutional determinants to FDIs (Mottaleb 2007; Dumludag 2009; Banga 2003; Edwards 1990; Globerman and Shapiro 2002; Hanson II 1996; Jaspensen, Anthony, and Knox 2000; Kirkpatrick, Parker, and Zhang 2004; Loree and Guisinger 1995; Wheeler and Mody 1992). Studying bureaucracy quality, the PRS Group (2004) demonstrated the positive relationship between government quality and FDI inflows.

As FDIs are generally long-term operations and irreversible, investors should be particularly attentive to the stability of their investment. Henceforth, Scheiner and Frey (1985) and Edwards (1990) linked political instability to a decrease in FDI inflows. However, other authors were less conclusive (Loree and Guisinger 1995; Hanson II 1996; Jaspensen, Anthony, and Knox 2000). The question of property rights is also often 
addressed as investors may be less lenient to invest in the host countries if there is a risk they may be expropriated too easily (Bellos and Subasat 2012). In the same line of arguments lies the fact that impartial courts and the legal enforcement of contracts are positive determinants (Drabek and Payne 2002). The same goes for the accountability of government and public officials, as the more accountable to their citizens they are the less likely it is for the political side to overrule judicial decisions (Jensen 2003).

The importance of the institutional determinants has been highlighted by the OECD (2002), considering that no other incentives are needed when this condition prevails. Despite this view being discussed by Wheeler and Moody (1992), Hines (1995), Habib and Zurawicki (2002), Li and Filer (2004), Henisz (2000), and Zhu (2007), Li (2005) demonstrated that when the "relation-based governance" replaces the "rule-based governance", protection of investors can still be without proper institutions. This would also induce that in these situations, firms will rely extensively upon private relationships to protect themselves - i.e., corruption (Bellos and Subasat 2012). Henceforth, Zhu (2007) demonstrated how firms play by the rules in a good governance system and bribe in a bad governance one. He argues then that "in more democratic and developed countries, increasing FDI inflows are likely to contribute to the reduction of corruption, while in non-democratic and less developed countries, a rise in FDI inflows is associated with a higher level of corruption".

\subsection{The Question of Corruption}

If it is commonly considered that institutional quality is positively linked with FDI inflows, the literature is mixed regarding corruption. Considered as an additional cost, a "tax", corruption has been argued to negatively affect FDI inflows (Al-Sadig 2009; Bardhan 1997). Habib and Zurawicki (2002) studied the impact of corruption on 89 countries and showed a negative correlation between the corruption level in the host country and inflows. Indeed, corruption distorts government efficiency, and increase direct costs. Especially, a lot of studies have been conducted in transition countries (Resmini 2000; Hellman, Jones, and Kaufmann 2002; Bevan, Estrin, and Meyer 2004; Caetano and Caleiro 2005; Cuervo-Cazurra 2006). This view is commonly addressed as the "sand the wheels' view.

However, other authors displayed a non-significant relationship between corruption and FDIs (Hines 1995; Wheeler and Mody 1992). Known as the "grease the wheels" opinion, this theory considers that corruption is likely to compensate for not-functioning institutions. When firms cannot operate smoothly because of too rigid regulations, they may be tempted to bribe to avoid spending too much time in contact with the administration (Leys 1965; Huntington 1970; Lui 1985; Beck and Maher 1986; Shleifer and Vishny 1993; Bardhan 1997; Kaufmann and Wei 1999; Aidt 2003; Méon and Sekkat 2005). Henceforth, corruption could be positively correlated with FDIs when the host country is badly governed. As such, we could expect to see FDIs lowered by corruption in developed countries. Reversely, FDIs could increase with corruption in developing countries. It is worth to be noted that some studies recused this hypothesis, showing no link between corruption and FDI in developed countries (see notably Wheeler and 
Mody 1992; Hines 1995; Habib and Zurawicki 2002; Henisz 2000). Stein and Daude (2001) also argued that one should be very cautious studying corruption with FDI as the former is presumably strongly intertwined with GDP per capita.

\section{Data}

This research project relies mainly on data from the World Bank, the United Nations Conference on Trade and Development (UNCTAD), and the CEPII for gravity analysis. Table 3 in Appendix shows the variables which I have used in the models, along with their descriptions and sources.

This studies focuses on the period between 2000 and 2018. Dependent variables have been thus extracted from the UNCTAD on this time period. As both unilateral stocks - i.e., the total FDI stocks a country has received in a given year - and bilateral stocks - i.e., the total FDI stocks a country has received in a given year per partner country are used in this study I extracted both data. Unfortunately, bilateral FDI stocks were available only up to 2012, which reduce the period of interest for the gravity analyses to follow. I use the UNCTAD database on investment, providing for each country the bilateral stock received per year. As the UNCTAD does not provide a conglomerate database, all countries have been downloaded and agglomerated manually. FDI stocks are in millions of current US dollars and 54,350 observations are hence available.

The Fraser Institute provides data on economic freedom. Particularly, its data on tariffs, trade barriers, labor laws, protection of property rights, and impartiality of courts have been used. The Economic Freedom Summary Index has also proven to be useful. For data on GDP as well as for economic information such as openness, inflation, population growth, and exchange rate, I used the World Bank Development Indicators (WDI). Information on tax compliance and ease to start a business come from the World Bank's Doing Business publication. I also utilized the World Governance Index for data on political stability and Corruption.

Finally, the CEPII database provides a complete gravity model dataset and the variables of interest have been extracted from there: distance, religious proximity, common language and currency, and legal origin. The World Trade Organization dataset contains information on Regional Trade Agreements which have been used as well.

\section{Methodology}

This study used panel data to investigate both economic and institutional determinants of FDIs. The study will conduct two sets of models: the first one being a classical unilateral model in which the dependent variable is the stocks of FDIs received by a country per year between 2000 and 2018. All countries are included in this analysis, provided they are populated with the relevant independent variables. The dependent variable is taken as a $\log$ value.

The second model is a gravity analysis based on the bilateral stocks of FDI received by 
the host country. Again, all countries are considered between 2001 and 2012 for reasons of availability of data. The bilateral FDI stocks come from the UNCTAD database. As Bénassy-Quéré et al. noted (2007) there are some advantages to work with stocks rather than flows. Stocks are less volatile than flows and are a better measure of capital ownership as per the study conducted by Devereux and Griffith (2002).

Table 4 and Table 5 display the countries studied in this paper depending on the model used. Notably, most of the countries from the European Union have been excluded from the sample due to their obvious peculiarity on FDI approach. Indeed, as the EU is now signing BITs and for all Member States, the study of treaties would have been flawed. Moreover, the EU is responding to other determinants, including but not limited to its common commercial policy, which are not studied in this paper.

In both unilateral and bilateral models fixed effects will be included to control for any unobservable time-invariant variables. As several authors demonstrated, one should use country-pair fixed effects as this is a better measure of the bilateral costs than the usual control variables (Egger and Nigai 2015; Agnosteva, Anderson, and Yotov 2014). This paper follows this best practice in the gravity models presented. The unilateral models are controlled for countries of destination fixed effects. The question of endogeneity between FDIs and trade policy variables is also dealt with using country-pair fixedeffects as Yotov et al. (2016) demonstrated.

Finally, time fixed effects are added to the different models to control for changes common to all countries in a given year. This also allows me to study the evolution of inward FDIs as a dependent variable rather than the raw amount of stocks. Henceforth, models including fixed effects will be studying the effect of independent variables on the increase (or decrease) of FDI inwards stocks.

For reasons of clarity, this paper distinguishes between economic (4.1) and institutional (4.2) determinants.

\subsection{Economic Determinants}

The first set of models study the economic determinants within the unilateral model. First, I controlled for GDP per capita as it is commonly argued that it is a strong driver for the attractiveness of FDI. I then study in Regression (1) of Table 7 the impact of macroeconomic stability factors which are Openness, Inflation, Population growth, and Exchange rate. Inflation, GDP per capita, and Exchange rate are positively correlated with inwards FDI stocks, being significant at the 0.01 level. Surprisingly, Openness is a negative driver in this regression. I then add in Regression (2) economic barriers in the form of Tariffs, Non-tariff trade barriers, and tax compliance. Tariff and tax compliance coefficients are positive while non-tariff trade barriers seem to negatively affect the inwards of FDI stocks. I also study the impact of business entry regulation through the Ease of Starting a business variable, demonstrating that this is a positive driver of FDI. Regression (3) of Table 7 summarizes the findings on economic determinants.

However, this naïve model may not be adequate as it does not control for time and country fixed effects. As such, Regressions 1 to 3 and 4 to 6 in Table 8 are solving these 
issues respectively. The same regressions parameters are used, only controlling for fixed effects and using the evolution of inward FDI stocks as the dependent variable. Adding the country and year fixed effects to the model allows confirming the positive impact of GDP per capita. However, all the other variables are overall not statistically significant, which could be explained by the peculiarity of the explanatory variables used which do not vary a lot over time.

Turning to Table 9, I replicate this analysis using bilateral investment data and a gravity model. As it has been demonstrated multiple times, a gravity equation must control for the links between the two countries. Henceforth, several control variables are added to the regressions. Those controls include the distance, GDP of both countries, GDP per capita of both countries, religious proximity, regional trade agreement that both countries are part of, common currency, and common official or primary language. I also add a dummy variable to indicate whether the pair of countries studied are engaged in a Bilateral Investment Treaty as this could theoretically be a strong driver of FDIs. Table 9 shows that openness, population growth, and ease to start a business are positive drivers when accounting for bilateral stocks of FDIs. On the contrary, inflation, exchange rate, tariffs, tax compliance, and non-tariff trade barriers are negatively correlated, even though the latter is not statistically significant. Surprisingly, the dummy variable for Investment Treaties is negative, albeit not significant in all regressions.

As for the first model, using a naïve gravity model suffers from serious limitations. To overcome those, I improve the equations by adding fixed effects. Following the best practice in gravity models, I use pair-fixed effects. Egger and Nigai (2015) and Agnosteva et al. (2014) demonstrated how using pairs for fixed effects rather than the country of destination is a better measure of bilateral costs than the standard variable. Of course, the variable such as common language, religious proximity, etc., are dropped by the model as being time-invariant. Table 10 summarizes the result, showing regressions both with pair-id fixed effects only and adding time fixed-effects. Openness, population growth, ease to start a business, tariffs, tax compliance, and investment treaties are positively correlated and statistically significant.

\subsection{Institutional Determinants}

Table 11 and onwards study the institutional determinants using the same methodology as above. If the economic determinants are added to these analyses for control, they do not change significantly so they are not displayed in the tables. Due to high collinearity between the variables, the Economic Freedom Summary Index, the protection of property rights, the impartiality of courts, and the corruption level are studied separately. As the issue is not present for political stability and labor market regulations, they are displayed each time.

Table 11 shows the respective impact of Economic freedom, protection of property rights, the impartiality of courts, and Corruption using a simple OLS on unilateral stocks. Economic freedom, protection of property rights, and impartiality of courts are all positive drivers as expected while corruption level is a deterrent. Surprisingly, political stability and labor market regulations are respectively negative and positive 
drivers. This is quite contrary to the initial assumptions, stating that investors would be reluctant to invest in an unstable country in which the labor law is not favorable.

Table 12 displays the results of the same analysis, adding country and time fixed effects following the methodology explained above. Moreover, aware of the fact that some of the variables are strongly intertwined to countries' regulations and that those can take some time to demonstrate the effect, I decided to add lagged effect to labor market regulations, protection of property rights, and impartial courts. As in the first study, country fixed effects do not change significantly the results and reinforce the conclusions of the simple OLS. However, none of the variables remain statistically significant when adding time fixed effect apart from the labor market regulations which stays positive.

Turning to Table 13, I replicate the analyses above using bilateral investment data and a gravity model. The process used for Table 9 has been replicated here, using the institutional variables in addition to the economic determinants. Computing simple OLS, Table 13 displays the positive impact of Political Stability, economic freedom, protection of property rights, and impartiality of courts. Labor market regulations and corruption levels are negative.

In Table 14, pair-id and year fixed effects are used. Most importantly, the protection of property rights is always positive with a strong correlation and statistical significance. Labor regulation is positively correlated - albeit not significant in Regression (8) - while political stability, economic freedom, impartial courts, and corruption are not significant controlling for time fixed effects. Investment treaties are also a strong driver, increasing FDI stocks by $12.3 \%$ on average as per Regression (6).

\subsection{Justification for Model Specifications and Robustness}

I used a Hausman test to choose between random and fixed effects models. The results, as well as the intuitions, confirmed the use of fixed-effects models. I decided to account for time and country/pair fixed effects as the joint significance of the time variables is satisfying. However, for some variables which do not vary over time, it seems preferable not to rely on the fixed effects results.

To deal with endogeneity, a generalized method of moments (GMM) dynamic estimators have been computed, showing similar results. Arellano and Bond (1991) demonstrated how GMM was able to control for unobserved individual effects, endogeneity, and simultaneity using lagged values. The use of time fixed effects has been proven to be jointly significant in the fixed-effects model.

Finally, I account for any potential heteroskedasticity in the models by calculating robust standard errors. 


\section{Results and Discussion}

\subsection{Summary of Findings}

Summaries of the findings are presented for economic and institutional determinants in Table 1 and Table 2 respectively showing the main results for the unilateral and bilateral models. Overall, the gravity models seem to have more explanatory power.

\begin{tabular}{|c|c|c|}
\hline \multirow{4}{*}{$\begin{array}{l}\text { VARIABLES } \\
\text { Openness }\end{array}$} & (1) & $(2)$ \\
\hline & \multicolumn{2}{|c|}{ D. FDI inward stocks (log) } \\
\hline & 0.000213 & $0.00205^{* *}$ \\
\hline & $(0.000441)$ & $(0.000802)$ \\
\hline \multirow[t]{2}{*}{ Inflation } & 0.000150 & -0.00121 \\
\hline & $(0.00287)$ & $(0.00251)$ \\
\hline \multirow[t]{2}{*}{ Population growth } & -0.00586 & $0.0506^{* *}$ \\
\hline & $(0.00623)$ & $(0.0211)$ \\
\hline \multirow[t]{2}{*}{ Exchange rate } & $4.24 \mathrm{e}-06$ & $-6.23 \mathrm{e}-05$ \\
\hline & $(3.00 \mathrm{e}-06)$ & $(3.96 \mathrm{e}-05)$ \\
\hline \multirow[t]{2}{*}{ Tariffs } & -0.0129 & $0.0524 * * *$ \\
\hline & $(0.0164)$ & $(0.0166)$ \\
\hline \multirow[t]{2}{*}{ Non-tariff trade barriers } & -0.00540 & 0.00569 \\
\hline & $(0.00816)$ & $(0.0199)$ \\
\hline \multirow[t]{2}{*}{ Tax compliance } & 0.0204 & $0.0431^{* * *}$ \\
\hline & $(0.0123)$ & $(0.0110)$ \\
\hline \multirow[t]{2}{*}{ Starting a business } & 0.000481 & $0.00463^{* * *}$ \\
\hline & $(0.00107)$ & $(0.00146)$ \\
\hline \multirow[t]{2}{*}{ Investment Treaties } & & $0.123^{* * *}$ \\
\hline & & $(0.0435)$ \\
\hline \multirow[t]{2}{*}{ Constant } & -0.765 & $-3.080 * * *$ \\
\hline & $(0.464)$ & $(0.831)$ \\
\hline Observations & 1,432 & 20,070 \\
\hline R-squared & 0.116 & 0.016 \\
\hline Country FE & YES & NO \\
\hline Number of countries & 126 & \\
\hline Pair-id FE & $\mathrm{NO}$ & YES \\
\hline Number of pair-id & & 3,025 \\
\hline Year FE & YES & YES \\
\hline Rho & 0.521 & 0.260 \\
\hline
\end{tabular}

Notes: Regressions include controls for GDP per capita for both Destinations and Origins.

Table 1: Economic determinants - Main results

Economic theory is split on the question to know whether tariff and trade barriers are promoting or preventing foreign direct investments. If both arguments seem valid, this study does not find robust evidence to opine in favor of one or another. Regression (2) in Table 1 shows a positive impact of tariffs on FDI in bilateral relationships. However, other trade barriers do not seem to have a statistical impact on the inward flows of 
FDI stocks while we could expect quantitative measures such as quotas to significantly prevent foreign firms from doing business in the host country and, as such, encourage them to relocate. The same goes for the ease to start a business, which seems overall positively correlated but I do not find any robust evidence on this variable.

If one could expect political stability to be a major driver in FDI, this does not seem to be the case. When studying a cross-country model (Table 11), the index is negatively correlated, meaning that investors seem to favor countries in which the stability is not acquired worldwide. Henceforth, stable countries are not necessarily the first target of investment. This discrepancy has been subject to heavy literature, in which it seems that investing in unstable countries could lead to higher profits, reasons as to why investors could prefer them.

\begin{tabular}{|c|c|c|}
\hline \multirow[b]{2}{*}{ VARIABLES } & (1) & $(2)$ \\
\hline & \multicolumn{2}{|c|}{ D. FDI inward stocks (log) } \\
\hline \multirow[t]{2}{*}{ Political Stability } & 0.00734 & -0.00235 \\
\hline & $(0.0142)$ & $(0.0244)$ \\
\hline \multirow[t]{2}{*}{ Labor market regulations (lagged) } & $0.0284^{*}$ & $0.0627 * * *$ \\
\hline & $(0.0146)$ & $(0.0206)$ \\
\hline \multirow[t]{2}{*}{ Protection of property rights (lagged) } & 0.0153 & $0.166^{* * *}$ \\
\hline & $(0.0193)$ & $(0.0447)$ \\
\hline \multirow[t]{2}{*}{ Investment Treaties } & & $0.123^{* * *}$ \\
\hline & & $(0.0438)$ \\
\hline \multirow[t]{2}{*}{ Constant } & $-1.017^{* *}$ & $-3.676^{* * *}$ \\
\hline & $(0.487)$ & $(0.885)$ \\
\hline Observations & 1,412 & 19,864 \\
\hline R-squared & 0.119 & 0.018 \\
\hline Country FE & YES & NO \\
\hline Number of countries & 125 & \\
\hline Pair-id FE & & YES \\
\hline Number of pair-id & & 2,948 \\
\hline Year FE & YES & YES \\
\hline Economic Determinants & YES & YES \\
\hline Rho & 0.560 & 0.268 \\
\hline
\end{tabular}

Notes: Regressions include controls for GDP per capita for both Destinations and Origins.

Table 2: Institutional determinants - Main results

Labor market regulation is one of the strongest and most stable negative drivers. An increase in labor market regulations seems to result in more FDIs. As this is likely to increase labor costs for investors, this result is quite surprising. However, one could find some plausible explanations. First, the issue of reverse-causality - discussed below - could induce that FDIs make labor laws stronger, by importing foreign knowledge and culture on the subject. Second, labor regulations are likely to come with a country's development, favored by and favoring FDI inflows.

Protection of property rights is also strongly increasing bilateral inflows of stocks 
in the host country. On a scale of 1 to 10, an increase of one unit in the protection of property rights increases the evolution of inflows of FDI in stocks by $16.6 \%$. This result is not surprising in its direction - one could easily assume why investors tend to prefer legal systems in which the risk of expropriation is reduced - the magnitude is quite striking. The same regression displays that the signature of a bilateral investment treaty increases FDI by "only" $12.3 \%$ on average. The result is usually explained by relying on international law literature. Bilateral Investment Treaties usually contain some clauses related to expropriation in which the confiscation of assets by the State is lawful under some conditions (mainly duly compensated and justified by public interest). When property rights are conferred by internal regulations, they are likely to be more advantageous to foreign investors as they do not apply solely to them. Moreover, it should be noted that, when a state increases property rights on its soil, it benefits all investors from every country, on the contrary to BITs applicable only to determined partners. However, even though economic freedom and impartial courts are usually positive drivers, they are not statistically significant in the latest gravity model controlling for pair-id and year fixed effects. The effect of corruption is mixed such as the study of the literature. Negatively correlated in simple OLS models, corruption is no longer significant when controlling for fixed effects. This is not surprising, as fixed-effects account only for time-varying factors and corruption is among the factors that do not vary extensively over time. Another explanation for this surprising result is the contested literature on the subject, as it is likely to see behaviors of firms be modified according to the country they are investing in. While corruption could be seen as a cost imposed on MCNs, it is also a way to bypass poor governance and badly conceived regulations.

\subsection{Limitations and Future Research}

The first limitation of this study is linked to fixed-effect models. Indeed, most of the variables used do not vary a lot over time, if not fixed, and are then not properly reflected by this method. As a part of the analysis provided here is to compare countries' policies on FDI, Fixed Effects could be unsuitable to our needs.

Another limitation is the question of reverse causality. As it has been frequently argued, FDI and GDP per capita, for instance, are strongly intertwined and it is not clear which one is leading the other. The same goes for corruption, which could be a change for foreign investors to compensate for a flawed regulation but at the same time represent a risk for expropriation. As some investors could see their interests reflected in corruption, it is not clear yet whether a low level of corruption is always an opportunity for investors, and hence attract FDI stocks. More generally, one can easily consider that investors pressure governments to improve institutions (see Selowsky and Martin 1997), and thus economic freedom index rises. For example, FDIs bring tax revenues for the government, which in turn could improve infrastructure industries (Adhikary 2011; Bhavan, Xu, and Zhong 2011; Azam 2010)

Even though the generalized method of moments (GMM) has been used to confirm the results, the endogeneity of the variables needs also to be kept in mind. Endogeneity is of particular importance, even more when policy variables are included in the model. 
Especially, governance quality and FDI could raise the endogeneity question. A twostage least squares technique could usefully be applied to this dataset.

The interaction between corruption and governance should be studied as well in further research as the mixed effect displayed in this paper could originate from the fact that investors do behave differently depending on the quality of governance in the host country.

Finally, an interesting way to go forward on the gravity analysis of FDIs is not to rely on the determinants of the host country - as this paper has done - but rather to look into the difference between the host and origin countries in those determinants. Henceforth, such a study could be conducted on the dataset created for this paper, hopefully with more conclusive results on the variables I have not been able to find robustness in.

\section{Conclusion}

To conclude, this paper does not find any robust evidence on the linkages between openness, inflation, population growth, and exchange rates on the inwards stocks of FDIs. However, the signature of Bilateral Investment Treaties is, as expected, a very strong driver. Investors enjoy more protection once the BIT is concluded, and the Investor-state dispute settlement clause is likely to play a role in this attractiveness. Overall, it seems that an increase of tariff increases the amount of FDIs, which could be explained by the relocation process foreign firms could be tempted to use to bypass those costs.

Protection of property rights is however the main driver of FDIs when studying institutional determinants. With an increase of $16.6 \%$ in the evolution of FDIs the year following the regulation per point of increase, this is more than any other variable, including BITs. Henceforth, a country willing to attract more investors should first and foremost guarantee MCNs rights regarding expropriations, giving them insurance that their property will not be taken away. 


\section{References}

Acemoglu, Daron, Simon Johnson, and S Robinson (2005). "Institutions as the Fundamental Cause of Long-Run Growth in P. Aghion and S. Durlauf,(Eds.), Handbook of Economic Growth, Volume 1, Part A". In: Publisher: Elsevier.

Addison, Tony and Almas Heshmati (2003). The new global determinants of FDI flows to developing countries: The importance of ICT and democratization. Issue: 2003/45. WIDER Discussion Paper. IsBN: 92-9190-477-5.

Adhikary, Bishnu Kumar (2011). "FDI, trade openness, capital formation, and economic growth in Bangladesh: a linkage analysis". In: International Journal of Business and Management 6.1. Publisher: Citeseer, p. 16. ISSN: 1833-3850.

Agnosteva, Delina E, James E Anderson, and Yoto V Yotov (2014). Intra-national trade costs: Measurement and aggregation. 0898-2937. National Bureau of Economic Research.

Aidt, Toke S (2003). "Economic analysis of corruption: a survey". In: The Economic Journal 113.491. Publisher: Oxford University Press Oxford, UK, F632-F652. ISSN: 0013-0133.

Alfaro, Laura et al. (Oct. 2004). "FDI and economic growth: the role of local financial markets". In: Journal of International Economics 64.1, pp. 89-112. ISSN: 00221996. DOI: 10.1016/S0022-1996(03) 00081-3. URL: https ://linkinghub . elsevier . com/retrieve/pii/S0022199603000813 (visited on 12/25/2020).

Arellano, Manuel and Stephen Bond (1991). "Some tests of specification for panel data: Monte Carlo evidence and an application to employment equations". In: The review of economic studies 58.2. Publisher: Wiley-Blackwell, pp. 277-297. Issn: 1467-937X.

Azam, Muhammad (2010). "An empirical analysis of the impacts of exports and foreign direct investment on economic growth in South Asia". In: Interdisciplinary Journal of Contemporary Research in Business 2.7, pp. 249-255.

Azman-Saini, W.N.W., Ahmad Zubaidi Baharumshah, and Siong Hook Law (Sept. 2010). "Foreign direct investment, economic freedom and economic growth: International evidence". In: Economic Modelling 27.5, pp. 1079-1089. ISSN: 02649993. DOI: $10.1016 / j$. econmod . 2010.04.001. URL: https : //linkinghub . elsevier . com/retrieve/pii/S0264999310000635 (visited on 12/22/2020).

Banga, Rashmi (2003). Impact of government policies and investment agreements on FDI inflows. working paper.

Bardhan, Pranab (1997). "Corruption and development: a review of issues". In: Journal of economic literature 35.3. Publisher: JSTOR, pp. 1320-1346. ISSN: 0022-0515.

Becchetti, Leonardo and Iftekhar Hasan (2005). The effects of (within and with EU) regional integration: Impact on real effective exchange rate volatility, institutional quality and growth for MENA countries. 9291907618. WIDER Research Paper.

Beck, Paul J and Michael W Maher (1986). "A comparison of bribery and bidding in thin markets". In: Economics letters 20.1. Publisher: Elsevier, pp. 1-5. ISSN: 0165-1765.

Bellos, Sotirios and Turan Subasat (May 2012). "Governance and foreign direct investment: a panel gravity model approach". In: International Review of Applied Economics 26.3, pp. 303-328. ISSN: 0269-2171, 1465-3486. DOI: 10 .1080/02692171. 2011 .587110. URL: http://www.tandfonline.com/doi/abs/10.1080/02692171. 2011.587110 (visited on 11/21/2020). 
Bénassy-Quéré, Agnès, Maylis Coupet, and Thierry Mayer (2007). "Institutional Determinants of Foreign Direct Investment". In: The World Economy 30.5, pp. 764782. ISSN: 0378-5920, 1467-9701. DOI: 10.1111/j.1467-9701.2007.01022.x. URL: http : / / doi.wiley.com/10.1111/j.1467-9701.2007.01022.x (visited on $11 / 22 / 2020)$.

Bevan, Alan, Saul Estrin, and Klaus Meyer (Feb. 1, 2004). "Foreign investment location and institutional development in transition economies". In: International Business Review 13.1, pp. 43-64. ISSN: 0969-5931. DOI: 10 . $1016 / \mathrm{j}$. ibusrev . 2003 . 05 . 005. URL: http : / / www . sciencedirect . com/science/article/pii / S0969593103001082 (visited on 12/21/2020).

Bhavan, T, Changsheng Xu, and Chunping Zhong (2011). "Determinants and growth effect of FDI in South Asian economies: Evidence from a panel data analysis". In: International Business Research 4.1. Publisher: Canadian Center of Science and Education, p. 43. ISSN: 1913-9004.

Caetano, José and Antonio Caleiro (2005). Corruption and Foreign Direct Investment. What kind of relationship is there? Documento de Trabalho.

Choong, Chee-Keong et al. (Mar. 2010). "Private capital flows, stock market and economic growth in developed and developing countries: A comparative analysis". In: Japan and the World Economy 22.2, pp. 107-117. ISSN: 09221425. DOI: 10.1016/j . japwor.2009.07.001. URL: https://linkinghub.elsevier.com/retrieve/pii/ S0922142509000334 (visited on 12/25/2020).

Cleeve, Emmanuel (2008). "How effective are fiscal incentives to attract FDI to SubSaharan Africa?" In: The Journal of Developing Areas. Publisher: JSTOR, pp. 135153. ISSN: 0022-037X.

Cohen, Wesley M and Daniel A Levinthal (1990). "Absorptive capacity: A new perspective on learning and innovation". In: Administrative science quarterly. Publisher: JSTOR, pp. 128-152. ISSN: 0001-8392.

Crespo, Nuno and Maria Paula Fontoura (2007). "Determinant factors of FDI spillovers - what do we really know?" In: World development 35.3. Publisher: Elsevier, pp. 410425. ISSN: 0305-750X.

Cuervo-Cazurra, Alvaro (Nov. 1, 2006). "Who cares about corruption?" In: Journal of International Business Studies 37.6, pp. 807-822. ISSN: 1478-6990. DOI: 10.1057/ palgrave . jibs . 8400223. URL: https : / / doi . org/10 . 1057 / palgrave . jibs . 8400223 (visited on 12/21/2020).

Demirbag, Mehmet, Martina McGuinness, and Hüseyin Altay (2010). "Perceptions of institutional environment and entry mode". In: Management International Review 50.2. Publisher: Springer, pp. 207-240. ISSN: 0938-8249.

Drabek, Zdenek and Warren Payne (2002). "The Impact of Transparency on Foreign Direct Investment". In: Journal of Economic Integration 17.4. Publisher: Center for Economic Integration, Sejong University, pp. 777-810. ISSN: 1225-651X. URL: https : //www.jstor.org/stable/23000835 (visited on 12/21/2020).

Dumludag, Devrim (2009). "An analysis of the determinants of foreign direct investment in Turkey: the role of the institutional context". In: Journal of Business Economics and Management 1. Publisher: Vilnius Gediminas Technical University, pp. 15-30. ISSN: 1611-1699. 
Dunning, John H (2003). "Determinants of foreign direct investment: globalizationinduced changes and the role of policies". In: Annual World Bank Conference on Development Economics, Europe, "Toward Pro-Poor Policies Aid, Institutions, and Globalization. Edited by Bertil Tungodden, Nicholas Stern, and Ivar Kolstad, pp. 279 290.

Edwards, Sebastian (1990). Capital flows, foreign direct investment, and debt-equity swaps in developing countries. 0898-2937. National Bureau of Economic Research.

Egger, Peter H and Sergey Nigai (2015). "Structural gravity with dummies only: Constrained ANOVA-type estimation of gravity models". In: Journal of International Economics 97.1. Publisher: Elsevier, pp. 86-99. ISSN: 0022-1996.

Fornes, Gaston and Alan Butt-Philip (2011). "Chinese MNEs and Latin America: a review". In: International Journal of Emerging Markets. Publisher: Emerald Group Publishing Limited. ISSN: 1746-8809.

Frenkel, Michael, Katja Funke, and Georg Stadtmann (2004). "A panel analysis of bilateral FDI flows to emerging economies". In: Economic systems 28.3. Publisher: Elsevier, pp. 281-300. ISSN: 0939-3625.

Froot and Stein (Nov. 1, 1991). "Exchange Rates and Foreign Direct Investment: An Imperfect Capital Markets Approach*". In: The Quarterly Journal of Economics 106.4, pp. 1191-1217. ISSN: 0033-5533. DOI: 10.2307/2937961. URL: https://doi . org/10.2307/2937961 (visited on 12/21/2020).

Ghodsi, Mahdi (Mar. 1, 2020). "How do technical barriers to trade affect foreign direct investment? Tariff jumping versus regulation haven hypotheses". In: Structural Change and Economic Dynamics 52, pp. 269-278. ISSN: 0954-349X. DOI: 10.1016/j . strueco.2019.11.008. URL: http://www.sciencedirect.com/science/article/ pii/S0954349X19302085 (visited on 12/22/2020).

Giroud, Axele and Joanna Scott-Kennel (2009). "MNE linkages in international business: A framework for analysis". In: International Business Review 18.6. Publisher: Elsevier, pp. 555-566. ISSN: 0969-5931.

Globerman, Steven and Daniel Shapiro (2002). "Global foreign direct investment flows: The role of governance infrastructure". In: World development 30.11. Publisher: Elsevier, pp. 1899-1919. ISSN: 0305-750X.

Habib, Mohsin and Leon Zurawicki (2002). "Corruption and foreign direct investment". In: Journal of international business studies 33.2. Publisher: Springer, pp. 291-307. ISSN: 0047-2506.

Hanson II, John R (1996). "Human capital and direct investment in poor countries". In: Explorations in Economic History 33.1. Publisher: Elsevier, pp. 86-106. ISSN: 0014-4983.

Hasli, Ho, and Ibrahim (2015). "Determinants of FDI inflow in Asia". In: Journal of Emerging Economies and Islamic Research 3.3, pp. 9-17. ISSN: 2289-2559.

Hayami, Yujiro et al. (2005). Development economics: From the poverty to the wealth of nations. Oxford University Press. ISBN: 0-19-927270-0.

Hellman, Joel S., Geraint Jones, and Daniel Kaufmann (Aug. 1, 2002). Far from Home: Do Foreign Investors Import Higher Standards of Governance in Transition Economies? SSRN Scholarly Paper ID 386900. Rochester, NY: Social Science Research Network. 
DOI: $10.2139 /$ ssrn . 386900. URL: https : //papers. ssrn . com/abstract $=386900$ (visited on $12 / 21 / 2020$ ).

Henisz, Witold J (2000). "The institutional environment for multinational investment". In: The Journal of Law, Economics, and Organization 16.2. Publisher: Oxford University Press, pp. 334-364. ISSN: 8756-6222.

Hines, James R (1995). Forbidden payment: Foreign bribery and American business after 197\%. 0898-2937. National Bureau of Economic Research.

Ho, CS and HA Rashid (2011). "Macroeconomic and country specific determinants of FDI". In: The Business Review 18.1, pp. 219-226.

Huntington, Samuel P (1970). "Political order in changing societies". In: VRÜ Verfassung und Recht in Übersee 3.2. Publisher: Nomos Verlagsgesellschaft mbH \& Co. KG, pp. 257-261. ISSN: 0506-7286.

IMF (2020). World Economic Report.

Irandoust Manuchehr, Johan Ericsson (2001). "On the causality between foreign direct investment and output: a comparative study". In: The International Trade Journal 15.1. Publisher: Taylor \& Francis, pp. 1-26. ISSN: 0885-3908.

Jadhav, Pravin (Jan. 1, 2012). "Determinants of foreign direct investment in BRICS economies: Analysis of economic, institutional and political factor". In: Procedia Social and Behavioral Sciences 37. Publisher: Elsevier, pp. 5-14. ISSN: 1877-0428. DOI: $10.1016 /$ j.sbspro.2012 .03 .270. URL: http: //www . sciencedirect . com/ science/article/pii/S1877042812007495 (visited on 12/25/2020).

Jaspensen, FZ, HA Anthony, and AD Knox (2000). "The effects of risk on private investment: Africa compared with other developing countries". In: Publisher: New York, ST Martin Press, USA.

Jensen, Nathan M. (2003). "Democratic Governance and Multinational Corporations: Political Regimes and Inflows of Foreign Direct Investment". In: International Organization 57.3. Publisher: [MIT Press, University of Wisconsin Press, Cambridge University Press, International Organization Foundation], pp. 587-616. ISSN: 00208183. URL: https://www.jstor.org/stable/3594838 (visited on 12/21/2020).

Kaufmann, Daniel, Aart Kraay, and Pablo Zoido-Lobatón (1999). Aggregating governance indicators. Vol. 2195. world Bank publications.

Kaufmann, Daniel and Shang-Jin Wei (1999). Does" grease money" speed up the wheels of commerce? 0898-2937. National bureau of economic research.

Kemp, Murray C. (1969). The pure theory of international trade and investment. Englewood Cliffs, N.J: Prentice-Hall. 359 pp. ISBN: 978-0-13-742544-0.

Kindleberger, Charles Poor (1969). "American business abroad". In: Publisher: Yale University Press.

Kirkpatrick, Colin, David Parker, and Yin-Fang Zhang (2004). Foreign direct investment in infrastructure in developing countries: does regulation make a difference?

Kumari, Reenu and Anil Kumar Sharma (Jan. 1, 2017). "Determinants of foreign direct investment in developing countries: a panel data study". In: International Journal of Emerging Markets 12.4. Publisher: Emerald Publishing Limited, pp. 658-682. ISSN: 1746-8809. DOI: 10.1108/IJoEM-10-2014-0169. URL: https ://doi .org/10.1108/ I JoEM-10-2014-0169 (visited on 12/21/2020). 
La Porta, R et al. (1999). "The quality of government". In: The Journal of Law, Economics, and Organization 15.1, pp. 222-279. ISSN: 00028282. URL: http://www . jstor.org/stable/2950944.

La Porta, Rafael, Florencio Lopez-de-Silanes, and Andrei Shleifer (June 2008). "The Economic Consequences of Legal Origins". In: Journal of Economic Literature 46.2, pp. 285-332. DOI: 10 . $1257 / \mathrm{jel}$. 46.2.285. URL: https : //www . aeaweb.org/ articles?id=10.1257/jel.46.2.285.

Leys, Colin (1965). "What is the Problem about Corruption?" In: The Journal of Modern African Studies 3.2. Publisher: JSTOR, pp. 215-230. ISSN: 0022-278X.

$\mathrm{Li}$, Shaomin (2005). "Why a poor governance environment does not deter foreign direct investment: The case of China and its implications for investment protection". In: Business Horizons 48.4, pp. 297-302. ISSN: 0007-6813. DOI: $10.1016 / \mathrm{j}$. bushor . 2004.06.002. URL: http://www . sciencedirect . com/science/article/pii/ S0007681305000443 (visited on 12/21/2020).

Li, Shaomin and L Filer (2004). "Governance environment and mode of investment". In: Academy of International Business Annual Meeting, Stockholm, Sweden.

Loree, David W and Stephen E Guisinger (1995). "Policy and non-policy determinants of US equity foreign direct investment". In: Journal of International Business Studies 26.2. Publisher: Springer, pp. 281-299. IsSN: 0047-2506.

Lui, Francis T (1985). "An equilibrium queuing model of bribery". In: Journal of political economy 93.4. Publisher: The University of Chicago Press, pp. 760-781. ISSN: 00223808 .

Mello, Luiz R. de (Oct. 1997). "Foreign direct investment in developing countries and growth: A selective survey". In: Journal of Development Studies 34.1, pp. 1-34. ISSN: 0022-0388, 1743-9140. DOI: 10.1080/00220389708422501. URL: http://www . tandfonline.com/doi/abs/10.1080/00220389708422501 (visited on 12/25/2020).

Méon, Pierre-Guillaume and Khalid Sekkat (2005). "Does corruption grease or sand the wheels of growth?" In: Public choice 122.1. Publisher: Springer, pp. 69-97. ISSN: 0048-5829.

Mhlanga, Nomathemba, Garrick Blalock, and Ralph Christy (2010). "Understanding foreign direct investment in the southern African development community: an analysis based on project-level data". In: Agricultural Economics 41.3, pp. 337-347. ISSN: 1574-0862. DOI: https://doi.org/10.1111/j.1574-0862.2010.00440.x. (Visited on $12 / 21 / 2020$ ).

Moosa, Imad A and Buly A Cardak (2006). "The determinants of foreign direct investment: An extreme bounds analysis". In: Journal of Multinational Financial Management 16.2. Publisher: Elsevier, pp. 199-211. IsSN: 1042-444X.

Moran, T (1998). "Foreign Direct Investment and Development: The New Policy Agenda for Developing Countries and Economies in Transition, Institute of International Economics". In: Washington, DC.

Mottaleb, Khondoker Abdul (2007). "Determinants of foreign direct investment and its impact on economic growth in developing countries". In:

Nayak, Dinkar and Rahul N Choudhury (2014). A selective review of foreign direct investment theories. ARTNeT Working Paper Series. 
Noorbakhsh, Farhad, Alberto Paloni, and Ali Youssef (2001). "Human capital and FDI inflows to developing countries: New empirical evidence". In: World development 29.9. Publisher: Elsevier, pp. 1593-1610. Issn: 0305-750X.

Paul, Justin (2016). "The rise of China: what, when, where, and why?" In: The International Trade Journal 30.3. Publisher: Taylor \& Francis, pp. 207-222. ISSN: 0885-3908.

Paul, Justin and Gurmeet Singh (2017). "The 45 years of foreign direct investment research: Approaches, advances and analytical areas". In: The World Economy 40.11. Publisher: Wiley Online Library, pp. 2512-2527. ISSN: 0378-5920.

Resmini, Laura (2000). "The Determinants of Foreign Direct Investment in the CEECs: New evidence from sectoral patterns". In: Economics of Transition and Institutional Change 8.3. _eprint: https://onlinelibrary.wiley.com/doi/pdf/10.1111/14680351.00060, pp. 665-689. ISSN: 1468-0351. DOI: https://doi.org/10.1111/14680351.00060. URL: https://onlinelibrary.wiley.com/doi/abs/10.1111/14680351.00060 (visited on $12 / 21 / 2020$ ).

Al-Sadig, Ali (2009). "The effects of corruption on FDI inflows". In: Cato J. 29. Publisher: HeinOnline, p. 267.

Saini, Neha and Monica Singhania (2018). "Determinants of FDI in developed and developing countries: a quantitative analysis using GMM". In: journal of economic studies. Publisher: Emerald Publishing Limited. ISSN: 0144-3585.

Selowsky, Marcelo and Ricardo Martin (1997). "Policy Performance and Output Growth in the Transition Economies". In: The American Economic Review 87.2, pp. 349353. ISSN: 00028282. URL: http://www.jstor.org/stable/2950944.

Shleifer, Andrei and Robert W Vishny (1993). "Corruption". In: The quarterly journal of economics 108.3. Publisher: MIT Press, pp. 599-617. ISSN: 1531-4650.

Smarzynska Javorcik, Beata (2004). "Does foreign direct investment increase the productivity of domestic firms? In search of spillovers through backward linkages". In: American economic review 94.3, pp. 605-627. IssN: 0002-8282.

Stein, Ernesto and Christian Daude (2001). "Institutions, integration and the location of foreign direct investment". In: New horizons for foreign direct investment, p. 101.

UNCTAD (2020). World Investment Report 2020. United Nations Conference for Trade and Development.

Welsh, Dianne HB, Ilan Alon, and Cecilia M Falbe (2006). "An examination of international retail franchising in emerging markets". In: Journal of small Business management 44.1. Publisher: Wiley Online Library, pp. 130-149. ISSN: 0047-2778.

Wheeler, David and Ashoka Mody (1992). "International investment location decisions: The case of US firms". In: Journal of international economics 33.1. Publisher: Elsevier, pp. 57-76. ISSN: 0022-1996.

Yotov, Yoto V et al. (2016). An advanced guide to trade policy analysis: The structural gravity model. World Trade Organization Geneva. ISBN: 92-870-4367-1.

Zhu, Boliang (2007). "Fortune or evil? The ef fects of inward foreign direct investment on corruption". In: Mini-APSA Conference at the Department of Political Science, Columbia University. 
8 Appendix 


\begin{tabular}{|c|c|c|}
\hline Variables & Descriptions & Sources \\
\hline GDP of Origin & Gross Domestic Product of Origin (current US\$) & WDI \\
\hline GDP of Destination & Gross Domestic Product of Destination (current US\$) & WDI \\
\hline GDP per capita of Origin & Gross Domestic Product per capita of Origin (current US\$) & WDI \\
\hline GDP per capita of Destination & Gross Domestic Product per capita of Destination (current US $\$$ ) & WDI \\
\hline Distance & $\begin{array}{l}\text { Weighted bilateral distance between origin and destination in kilo- } \\
\text { meter (population weighted). }\end{array}$ & CEPII \\
\hline Religious Proximity & $\begin{array}{l}\text { Religious proximity (Disdier and Mayer, 2007) is an idex composed } \\
\text { of the shares of people practicing the different religions in the host } \\
\text { and origin countries. Bounded between } 0 \text { and } 1 \text {, the maximum value } \\
\text { is achieved when both countries share the same religion practiced } \\
\text { by majority of the population. }\end{array}$ & $\begin{array}{l}\text { La Porta et al. } 1999 \text { and } \\
\text { CIA World Factbook }\end{array}$ \\
\hline Common Legal Origins after Transition & $\begin{array}{l}\text { Dummy if origin and destination share common legal origins after } \\
\text { transition }\end{array}$ & $\begin{array}{l}\text { Rafael La Porta, } \\
\text { Lopez-de-Silanes, and } \\
\text { Shleifer } 2008\end{array}$ \\
\hline Common Currency & $\begin{array}{l}\text { Dummy equal to } 1 \text { if countries share the same currency in a given } \\
\text { year. }\end{array}$ & CEPII \\
\hline Common Language & $\begin{array}{l}\text { Dummy equal to } 1 \text { if countries share common official or primary } \\
\text { language. }\end{array}$ & CEPII \\
\hline Regional Trade Agreement & Dummy if origin and destination share Regional Trade Agreement & WTO data \\
\hline Inward Stocks of FDIs & Foreign Direct Investment inward stocks in million of current $\$$ US. & UNCTAD \\
\hline Year & Numeric, from 2000 to 2018 & \\
\hline Openness & Volume of Trade as \% of GDP. & WDI \\
\hline Inflation & Inflation, consumer prices (annual \%). & WDI \\
\hline Population Growth & Population growth (annual \%). & WDI \\
\hline Exchange Rate & $\begin{array}{l}\text { Official exchange rate (Local Currency Unit per US\$, period aver- } \\
\text { age) }\end{array}$ & WDI \\
\hline
\end{tabular}

Table 3: Data Description 
Tariffs

Non-tariff trade barriers

Tax compliance

Starting a business

Political Stability

Labor market regulations

Economic freedom summary Index

Protection of property rights

Impartial courts

Corruption

Investment Treaties
Aggregate based on Revenues from Trade Taxes (as a \% of trade sector), Mean Tariff Rate, and Standard Deviation of Tariff Rates. Rescaled so that higher values indicate higher tariffs.

EFW

Based on survey, examine to which extent trade barriers reduce the ability of imported foods to compete in the domestic market. Rescaled so that higher values indicate higher barriers.

EFW

Measure of the time required per year to pay taxes. Rescaled so that higher values indicate higher regulatory burden.

Measure of the amount of time and money needed to start a new limited liability company. Countries in which it is easier are given higher rating.

Political Stability and Absence of Violence/Terrorism measures perceptions of the likelihood of political instability and/or politically motivated violence, including terrorism.

Aggregate based on Hiring Regulations and Minimum Wage, Hiring and Firing Regulations, Centralized Collective Bargaining, Hours regulations, Mandated Cost of Worker Dismissal and Conscription. Rescaled so that higher values indicate stronger labor market regulations.

Measures the degree of economic freedom in the world.

Aggregate based on the Global Competitiveness Report survey, Property Rights for Men from V-Dem, and the Property Rights and RuleBased Governance from the World Bank. Higher score indicates higher protection.

Aggregate based on the Global Competitiveness Report survey, the Judicial Corrupt Decision from V-Dem dataset, and the Rule of Law indicators from WGI. Higher values indicate higher impartiality.

Based on the Control of Corruption Index. Rescaled so that higher values represent higher corruption levels.

Dummy equal to 1 if origin and destination share Bilateral Investment Treaties.
EFW

WGI

Doing Business

Doing Business

WGI

EFW

EFW

EFW

UNCTAD 


\begin{tabular}{lccccc}
\hline VARIABLES & Observations & Mean & St. Dev. & Min & Max \\
\hline & & & & & \\
Years & 3,329 & 2,009 & 5.476 & 2,000 & 2,018 \\
Openness & 2,970 & 87.98 & 51.32 & 0.167 & 437.3 \\
Inflation & 2,905 & 5.388 & 7.807 & -60.50 & 168.6 \\
Population growth & 3,271 & 1.504 & 1.568 & -9.081 & 17.51 \\
Exchange rate & 2,879 & 677.1 & 2,763 & 0.0445 & 40,864 \\
Political Stability & 3,066 & 6.244 & 1.773 & 0.336 & 9.564 \\
Impartial courts & 2,791 & 4.721 & 1.297 & 2.130 & 8.005 \\
Protection of property rights & 2,787 & 5.336 & 1.035 & 2.422 & 7.932 \\
Tariffs & 2,537 & 2.597 & 1.338 & 0 & 10 \\
Non-tariff trade barriers & 2,250 & 4.170 & 1.233 & 0.315 & 10 \\
Labor market regulations & 2,503 & 3.690 & 1.398 & 0.275 & 7.549 \\
Tax compliance & 2,504 & 3.162 & 2.038 & 0.135 & 10 \\
Starting a business & 2,287 & 73.19 & 18.66 & 2.206 & 99.96 \\
Corruption & 3,067 & 5.110 & 1.998 & 0.0600 & 8.737 \\
FDI inward stocks (log) & 3,309 & 8.885 & 2.655 & 0 & 15.88 \\
GDP per capita (log) & 3,170 & 8.340 & 1.566 & 4.727 & 11.69 \\
& & & & & \\
\hline
\end{tabular}




\begin{tabular}{|c|c|c|}
\hline Afghanistan & Grenada & Nigeria \\
\hline Albania & Guatemala & Norway \\
\hline Algeria & Guinea & Oman \\
\hline Angola & Guinea-Bissau & Pakistan \\
\hline Antigua and Barbuda & Guyana & Palau \\
\hline Argentina & Haiti & Panama \\
\hline Armenia & Honduras & Papua New Guinea \\
\hline Aruba & Hungary & Paraguay \\
\hline Australia & Iceland & Peru \\
\hline Azerbaijan & India & Philippines \\
\hline Bahamas & Indonesia & Poland \\
\hline Bahrain & Iran (Islamic Republic of) & Qatar \\
\hline Bangladesh & Iraq & Romania \\
\hline Barbados & Israel & Russian Federation \\
\hline Belarus & Jamaica & Rwanda \\
\hline Benin & Japan & Saint Kitts and Nevis \\
\hline Bhutan & Jordan & Samoa \\
\hline Bosnia and Herzegovina & Kazakhstan & Saudi Arabia \\
\hline Botswana & Kenya & Senegal \\
\hline Brazil & Kiribati & Serbia \\
\hline Brunei Darussalam & Korea, Republic of & Seychelles \\
\hline Bulgaria & Kuwait & Sierra Leone \\
\hline Burkina Faso & Kyrgyzstan & Singapore \\
\hline Burundi & Latvia & Slovakia \\
\hline Cambodia & Lebanon & Slovenia \\
\hline Cameroon & Lesotho & Solomon Islands \\
\hline Canada & Liberia & South Africa \\
\hline Chad & Libya & Sri Lanka \\
\hline Chile & Lithuania & Sudan \\
\hline China & Madagascar & Sweden \\
\hline Colombia & Malawi & Syrian Arab Republic \\
\hline Comoros & Malaysia & Tajikistan \\
\hline Congo & Maldives & Tanzania, United Republic of \\
\hline Costa Rica & Mali & Thailand \\
\hline Croatia & Malta & Timor-Leste \\
\hline Cyprus & Mauritania & Togo \\
\hline Denmark & Mauritius & Tonga \\
\hline Djibouti & Mexico & Tunisia \\
\hline Dominica & Micronesia (Federated States of) & Turkey \\
\hline Dominican Republic & Moldova, Republic of & Uganda \\
\hline Ecuador & Mongolia & Ukraine \\
\hline Egypt & Montenegro & United Arab Emirates \\
\hline El Salvador & Morocco & United Kingdom \\
\hline Equatorial Guinea & Mozambique & United States of America \\
\hline Estonia & Myanmar & Uruguay \\
\hline Ethiopia & Namibia & Vanuatu \\
\hline Gabon & Nepal & Viet Nam \\
\hline Gambia & New Zealand & Zambia \\
\hline Georgia & Nicaragua & \\
\hline Ghana & Niger & \\
\hline
\end{tabular}

Table 4: Countries used in unilateral models 


\begin{tabular}{|c|c|c|}
\hline Afghanistan & Jamaica & Singapore \\
\hline Albania & Japan & Slovak Republic \\
\hline Algeria & Kazakhstan & Slovenia \\
\hline Angola & Kenya & Solomon Islands \\
\hline Antigua and Barbuda & Korea, Rep. & South Africa \\
\hline Armenia & Kuwait & Sri Lanka \\
\hline Aruba & Kyrgyz Republic & St. Kitts and Nevis \\
\hline Australia & Lao PDR & $\begin{array}{l}\text { St. Vincent and the } \\
\text { Grenadines }\end{array}$ \\
\hline Bahrain & Latvia & Sudan \\
\hline Benin & Lebanon & Suriname \\
\hline Bhutan & Lesotho & Sweden \\
\hline Bosnia and Herzegovina & Liberia & Switzerland \\
\hline Brazil & Libya & Syrian Arab Republic \\
\hline Brunei Darussalam & Lithuania & Tajikistan \\
\hline Bulgaria & Macao SAR, China & Tanzania \\
\hline Burundi & Madagascar & Thailand \\
\hline Cabo Verde & Malawi & Tonga \\
\hline Cameroon & Malaysia & Tunisia \\
\hline Canada & Maldives & Turkey \\
\hline Chile & Mali & Uganda \\
\hline China & Malta & Ukraine \\
\hline Costa Rica & Mauritania & United Arab Emirates \\
\hline Cote d'Ivoire & Mexico & United Kingdom \\
\hline Croatia & Moldova & United States \\
\hline Cyprus & Mongolia & Uruguay \\
\hline Czech Republic & Morocco & Vanuatu \\
\hline Denmark & Mozambique & Venezuela, RB \\
\hline Dominica & Myanmar & Vietnam \\
\hline Dominican Republic & Nepal & Zambia \\
\hline Ecuador & New Zealand & \\
\hline Egypt, Arab Rep. & Nicaragua & \\
\hline El Salvador & Niger & \\
\hline Eswatini & Nigeria & \\
\hline Ethiopia & North Macedonia & \\
\hline Gabon & Norway & \\
\hline Gambia, The & Oman & \\
\hline Georgia & Pakistan & \\
\hline Ghana & Palau & \\
\hline Guatemala & Panama & \\
\hline Guinea & Papua New Guinea & \\
\hline Haiti & Paraguay & \\
\hline Honduras & Peru & \\
\hline Hong Kong SAR, China & Philippines & \\
\hline Hungary & Qatar & \\
\hline Iceland & Russian Federation & \\
\hline India & Samoa & \\
\hline Indonesia & Saudi Arabia & \\
\hline Iran, Islamic Rep. & Senegal & \\
\hline Iraq & Seychelles & \\
\hline Israel & Sierra Leone & \\
\hline
\end{tabular}

Table 5: Countries used in bilateral models 


\begin{tabular}{|c|c|c|c|c|c|c|c|c|c|c|c|c|c|c|c|c|}
\hline & $(1)$ & $(2)$ & $(3)$ & $(4)$ & $(5)$ & $(6)$ & $(7)$ & $(8)$ & $(9)$ & $(10)$ & $(11)$ & $(12)$ & $(13)$ & $(14)$ & $(15)$ & $(16)$ \\
\hline (1) FDI inward stocks & 1.00 & & & & & & & & & & & & & & & \\
\hline (2) GDP per capita & 0.68 & 1.00 & & & & & & & & & & & & & & \\
\hline (3) Openness & 0.12 & 0.24 & 1.00 & & & & & & & & & & & & & \\
\hline (4) Inflation & -0.19 & -0.33 & -0.09 & 1.00 & & & & & & & & & & & & \\
\hline (5) Population growth & -0.19 & -0.21 & -0.06 & 0.06 & 1.00 & & & & & & & & & & & \\
\hline (6) Exchange rate & 0.03 & -0.15 & 0.03 & 0.14 & 0.02 & 1.00 & & & & & & & & & & \\
\hline (7) Tariffs & -0.17 & -0.33 & -0.29 & 0.21 & 0.19 & 0.17 & 1.00 & & & & & & & & & \\
\hline (8) Non-tariff trade barriers & -0.36 & -0.55 & -0.29 & 0.20 & 0.08 & 0.14 & 0.35 & 1.00 & & & & & & & & \\
\hline (9) Tax compliance & -0.19 & -0.37 & -0.13 & 0.10 & -0.09 & 0.22 & 0.23 & 0.39 & 1.00 & & & & & & & \\
\hline (10) Starting a business & 0.42 & 0.50 & 0.15 & -0.16 & -0.30 & -0.07 & -0.26 & -0.34 & -0.36 & 1.00 & & & & & & \\
\hline (11) Political Stability & 0.24 & 0.58 & 0.31 & -0.21 & -0.18 & -0.08 & -0.25 & -0.45 & -0.31 & 0.29 & 1.00 & & & & & \\
\hline (12) Labor market regulations & -0.01 & -0.22 & -0.14 & 0.08 & -0.03 & 0.19 & 0.13 & 0.32 & 0.28 & -0.17 & -0.27 & 1.00 & & & & \\
\hline (13) Corruption & -0.47 & -0.76 & -0.21 & 0.26 & 0.17 & 0.16 & 0.22 & 0.61 & 0.45 & -0.45 & -0.71 & 0.31 & 1.00 & & & \\
\hline (14) Protection of property rights & 0.51 & 0.73 & 0.16 & -0.25 & -0.15 & -0.13 & -0.12 & -0.60 & -0.41 & 0.48 & 0.62 & -0.27 & -0.83 & 1.00 & & \\
\hline (15) Impartial courts & 0.50 & 0.74 & 0.21 & -0.26 & -0.07 & -0.16 & -0.15 & -0.65 & -0.50 & 0.45 & 0.67 & -0.36 & -0.94 & 0.86 & 1.00 & \\
\hline (16) Years & 0.18 & 0.09 & -0.08 & -0.15 & 0.04 & 0.07 & -0.07 & 0.12 & -0.16 & 0.36 & -0.07 & -0.05 & 0.06 & 0.04 & -0.05 & 1.00 \\
\hline
\end{tabular}

Table 6: Correlations Results 


\begin{tabular}{|c|c|c|c|}
\hline \multirow{4}{*}{$\begin{array}{l}\text { VARIABLES } \\
\text { GDP per capita }\end{array}$} & \multirow{2}{*}{\multicolumn{3}{|c|}{$\begin{array}{l}(2) \\
\text { FDI inward stocks (log) }\end{array}$}} \\
\hline & & & \\
\hline & $1.078^{* * *}$ & $1.061^{* * *}$ & $0.980^{* * *}$ \\
\hline & $(0.0278)$ & $(0.0345)$ & $(0.0410)$ \\
\hline Openness & $-0.00713^{* * *}$ & $-0.00399 * * *$ & $-0.00210^{*}$ \\
\hline Inflation & $0.0237^{* * *}$ & 0.00551 & 0.00860 \\
\hline & $(0.00593)$ & $(0.00479)$ & $(0.00731)$ \\
\hline Population growth & $\begin{array}{c}-0.0802^{* * *} \\
(0.0208)\end{array}$ & $\begin{array}{l}-0.0449^{*} \\
(0.0245)\end{array}$ & $\begin{array}{l}-0.0153 \\
(0.0265)\end{array}$ \\
\hline Exchange rate & $\begin{array}{c}0.000136^{* * *} \\
(1.57 \mathrm{e}-05)\end{array}$ & $\begin{array}{l}7.85 \mathrm{e}-05^{* * *} \\
(1.30 \mathrm{e}-05)\end{array}$ & $\begin{array}{c}8.26 \mathrm{e}-05^{* * * *} \\
(1.30 \mathrm{e}-05)\end{array}$ \\
\hline Tariffs & & $\begin{array}{c}0.0886^{* *} \\
(0.0392)\end{array}$ & $\begin{array}{c}0.0512 \\
(0.0458)\end{array}$ \\
\hline Non-tariff trade barriers & & $\begin{array}{c}-0.0923^{* *} \\
(0.0378)\end{array}$ & $\begin{array}{l}-0.0390 \\
(0.0401)\end{array}$ \\
\hline Tax compliance & & $\begin{array}{c}0.141^{* * *} \\
(0.0186)\end{array}$ & $\begin{array}{c}0.0793^{* * *} \\
(0.0227)\end{array}$ \\
\hline Starting a business & & & $\begin{array}{l}0.0146^{* * *} \\
(0.00281)\end{array}$ \\
\hline Constant & $\begin{array}{l}0.602^{* *} \\
(0.259)\end{array}$ & $\begin{array}{c}0.843^{* *} \\
(0.419)\end{array}$ & $\begin{array}{l}0.180 \\
(0.497)\end{array}$ \\
\hline Observations & 2,439 & 1,809 & 1,434 \\
\hline R-squared & 0.391 & 0.465 & 0.492 \\
\hline Adjusted R-squared & 0.389 & 0.463 & 0.489 \\
\hline
\end{tabular}

Robust standard errors in parentheses

*** $\mathrm{p}<0.01,{ }^{* *} \mathrm{p}<0.05,{ }^{*} \mathrm{p}<0.1$

Table 7: Economic Determinants 


\begin{tabular}{|c|c|c|c|c|c|c|}
\hline \multirow[b]{2}{*}{ VARIABLES } & (1) & $(2)$ & $(3)$ & (4) & $(5)$ & (6) \\
\hline & \multicolumn{6}{|c|}{ D. FDI inward stocks (log) } \\
\hline \multirow[t]{2}{*}{ GDP per capita } & $-0.0565^{* * *}$ & $-0.0509^{* * *}$ & -0.0421 & 0.0168 & $0.0718^{*}$ & $0.116^{* *}$ \\
\hline & $(0.0160)$ & $(0.0156)$ & $(0.0262)$ & $(0.0380)$ & $(0.0416)$ & $(0.0528)$ \\
\hline \multirow[t]{2}{*}{ Openness } & 0.000665 & -0.000203 & $-3.77 \mathrm{e}-05$ & 0.000376 & -0.000189 & 0.000213 \\
\hline & $(0.000415)$ & $(0.000400)$ & $(0.000465)$ & $(0.000423)$ & $(0.000440)$ & $(0.000441)$ \\
\hline \multirow[t]{2}{*}{ Inflation } & $0.00196^{*}$ & -0.000191 & $-5.25 \mathrm{e}-05$ & 0.00182 & $6.45 \mathrm{e}-05$ & 0.000150 \\
\hline & $(0.00112)$ & $(0.00111)$ & $(0.00130)$ & $(0.00146)$ & $(0.00204)$ & $(0.00287)$ \\
\hline \multirow[t]{2}{*}{ Population growth } & 0.00477 & 0.000275 & -0.00115 & -0.00248 & -0.00556 & -0.00586 \\
\hline & $(0.00794)$ & $(0.00720)$ & $(0.00816)$ & $(0.00901)$ & $(0.00533)$ & $(0.00623)$ \\
\hline \multirow[t]{2}{*}{ Exchange rate } & $-6.16 \mathrm{e}-06$ & $-3.96 \mathrm{e}-06$ & $-8.56 \mathrm{e}-07$ & $4.38 \mathrm{e}-07$ & $1.84 \mathrm{e}-06$ & $4.24 \mathrm{e}-06$ \\
\hline & $(7.08 \mathrm{e}-06)$ & $(6.55 \mathrm{e}-06)$ & $(6.86 \mathrm{e}-06)$ & $(4.89 \mathrm{e}-06)$ & $(3.57 \mathrm{e}-06)$ & $(3.00 \mathrm{e}-06)$ \\
\hline \multirow[t]{2}{*}{ Tariffs } & & -0.00293 & 0.00132 & & -0.0180 & -0.0129 \\
\hline & & $(0.00891)$ & $(0.0125)$ & & $(0.0111)$ & $(0.0164)$ \\
\hline \multirow[t]{2}{*}{ Non-tariff trade barriers } & & $-0.0219 * * *$ & $-0.0223^{* *}$ & & -0.000965 & -0.00540 \\
\hline & & $(0.00797)$ & $(0.00987)$ & & $(0.00716)$ & $(0.00816)$ \\
\hline \multirow[t]{2}{*}{ Tax compliance } & & $0.0264^{* * *}$ & $0.0240^{* * *}$ & & 0.0146 & 0.0204 \\
\hline & & $(0.00637)$ & $(0.00827)$ & & $(0.00941)$ & $(0.0123)$ \\
\hline \multirow[t]{2}{*}{ Starting a business } & & & $-0.00200 * * *$ & & & 0.000481 \\
\hline & & & $(0.000725)$ & & & $(0.00107)$ \\
\hline \multirow[t]{2}{*}{ Constant } & $0.520^{* * *}$ & $0.582^{* * *}$ & $0.645^{* * *}$ & -0.0676 & -0.435 & -0.765 \\
\hline & $(0.137)$ & $(0.155)$ & $(0.233)$ & $(0.308)$ & $(0.340)$ & $(0.464)$ \\
\hline Observations & 2,314 & 1,752 & 1,432 & 2,314 & 1,752 & 1,432 \\
\hline R-squared & 0.011 & 0.032 & 0.042 & 0.065 & 0.115 & 0.116 \\
\hline Country FE & YES & YES & YES & YES & YES & YES \\
\hline Number of countries & 148 & 127 & 126 & 148 & 127 & 126 \\
\hline Year FE & NO & NO & NO & YES & YES & YES \\
\hline Rho & 0.128 & 0.181 & 0.172 & 0.0962 & 0.338 & 0.521 \\
\hline
\end{tabular}

Robust Standard errors in parentheses

*** $\mathrm{p}<0.01,{ }^{* *} \mathrm{p}<0.05,{ }^{*} \mathrm{p}<0.1$

Table 8: Economic Determinants with Fixed Effects 


\begin{tabular}{|c|c|c|c|}
\hline \multirow{2}{*}{ VARIABLES } & $(1)$ & $(2)$ & $(3)$ \\
\hline & \multicolumn{3}{|c|}{ FDI inward stocks (log) } \\
\hline \multirow[t]{2}{*}{ Distance } & $-0.541^{* * *}$ & $-0.624^{* * *}$ & $-0.579 * * *$ \\
\hline & $(0.0176)$ & $(0.0188)$ & $(0.0221)$ \\
\hline \multirow[t]{2}{*}{ GDP of Destination $(\log )$} & $0.606^{* * *}$ & $0.696^{* * *}$ & $0.799^{* * *}$ \\
\hline & $(0.00845)$ & $(0.0109)$ & $(0.0160)$ \\
\hline \multirow[t]{2}{*}{ GDP of Origin (log) } & $0.425^{* * *}$ & $0.438^{* * *}$ & $0.398^{* * *}$ \\
\hline & $(0.00689)$ & $(0.00738)$ & $(0.00866)$ \\
\hline \multirow[t]{2}{*}{ GDP per capita - Destination } & $-0.126^{* * *}$ & $-0.271^{* * *}$ & $-0.396^{* * *}$ \\
\hline & $(0.0130)$ & $(0.0176)$ & $(0.0226)$ \\
\hline \multirow[t]{2}{*}{ GDP per capita - Origin } & $0.636^{* * *}$ & $0.695^{* * *}$ & $0.663^{* * *}$ \\
\hline & $(0.00960)$ & $(0.0105)$ & $(0.0129)$ \\
\hline \multirow[t]{2}{*}{ Religious Proximity } & $0.353^{* * *}$ & $0.414^{* * *}$ & $0.276^{* * *}$ \\
\hline & $(0.0525)$ & $(0.0558)$ & $(0.0664)$ \\
\hline \multirow[t]{2}{*}{ Regional Trade Agreement } & $0.468^{* * *}$ & $0.364^{* * *}$ & $0.432^{* * *}$ \\
\hline & $(0.0367)$ & $(0.0388)$ & $(0.0455)$ \\
\hline \multirow[t]{2}{*}{ Common Currency } & $0.735^{* * *}$ & $0.504^{* *}$ & 0.00916 \\
\hline & $(0.200)$ & $(0.230)$ & $(0.260)$ \\
\hline \multirow[t]{2}{*}{ Common language } & $1.389 * * *$ & $1.409^{* * *}$ & $1.597^{* * *}$ \\
\hline & $(0.0396)$ & $(0.0425)$ & $(0.0513)$ \\
\hline \multirow[t]{2}{*}{ Openness } & $0.00845^{* * *}$ & $0.00778^{* * *}$ & $0.00625^{* * *}$ \\
\hline & $(0.000280)$ & $(0.000313)$ & $(0.000371)$ \\
\hline \multirow[t]{2}{*}{ Inflation } & $-0.0192^{* * *}$ & $-0.0193^{* * *}$ & $-0.0146^{* * *}$ \\
\hline & $(0.00212)$ & $(0.00229)$ & $(0.00357)$ \\
\hline \multirow[t]{2}{*}{ Population growth } & -0.00362 & $-0.0273^{* *}$ & $0.0416^{* * *}$ \\
\hline & $(0.00958)$ & $(0.0119)$ & $(0.0139)$ \\
\hline \multirow[t]{2}{*}{ Exchange rate } & $-3.28 \mathrm{e}-05^{* * *}$ & $-4.01 \mathrm{e}-06$ & $-1.55 \mathrm{e}-05^{*}$ \\
\hline & $(6.88 \mathrm{e}-06)$ & $(7.91 \mathrm{e}-06)$ & $(9.06 \mathrm{e}-06)$ \\
\hline \multirow[t]{2}{*}{ Tariffs } & & $-0.160 * * *$ & $-0.257^{* * *}$ \\
\hline & & $(0.0145)$ & $(0.0180)$ \\
\hline \multirow[t]{2}{*}{ Non-tariff trade barriers } & & -0.0171 & -0.0125 \\
\hline & & $(0.0158)$ & $(0.0192)$ \\
\hline \multirow[t]{2}{*}{ Tax compliance } & & $-0.0614^{* * *}$ & $-0.0417 * * *$ \\
\hline & & $(0.00684)$ & $(0.00866)$ \\
\hline \multirow[t]{2}{*}{ Starting a business } & & & $0.0149 * * *$ \\
\hline & & & $(0.00150)$ \\
\hline \multirow[t]{2}{*}{ Investment Treaties } & $-0.125^{* * *}$ & $-0.200 * * *$ & -0.0311 \\
\hline & $(0.0283)$ & $(0.0297)$ & $(0.0355)$ \\
\hline \multirow[t]{2}{*}{ Constant } & $-24.42^{* * *}$ & $-24.87 * * *$ & $-26.32^{* * *}$ \\
\hline & $(0.258)$ & $(0.309)$ & $(0.412)$ \\
\hline Observations & 34,797 & 30,815 & 21,029 \\
\hline R-squared & 0.408 & 0.424 & 0.415 \\
\hline Adjusted R-squared & 0.407 & 0.424 & 0.414 \\
\hline
\end{tabular}

Robust standard errors in parentheses *** $\mathrm{p}<0.01,{ }^{* *} \mathrm{p}<0.05, * \mathrm{p}<0.1$

Table 9: Economic Determinants - Gravity Model 


\begin{tabular}{|c|c|c|c|c|c|c|}
\hline \multirow[b]{2}{*}{ VARIABLES } & (1) & (2) & $(3)$ & $(4)$ & $(5)$ & $(6)$ \\
\hline & \multicolumn{6}{|c|}{ D. FDI inward stocks (log) } \\
\hline \multirow[t]{2}{*}{ Openness } & 0.000203 & 0.000438 & 0.000149 & $0.000947^{*}$ & $0.00192^{* * *}$ & $0.00205^{* *}$ \\
\hline & $(0.000470)$ & $(0.000525)$ & $(0.000693)$ & $(0.000531)$ & $(0.000594)$ & $(0.000802)$ \\
\hline \multirow[t]{2}{*}{ Inflation } & $-0.00295^{* *}$ & $-0.00351^{* *}$ & $-0.00450^{* *}$ & -0.00104 & -0.000301 & -0.00121 \\
\hline & $(0.00145)$ & $(0.00147)$ & $(0.00214)$ & $(0.00158)$ & $(0.00165)$ & $(0.00251)$ \\
\hline \multirow[t]{2}{*}{ Population growth } & $0.0370^{* *}$ & $0.0432^{* *}$ & $0.0545^{* * *}$ & 0.0257 & $0.0350 *$ & $0.0506^{* *}$ \\
\hline & $(0.0168)$ & $(0.0182)$ & $(0.0211)$ & $(0.0170)$ & $(0.0183)$ & $(0.0211)$ \\
\hline \multirow[t]{2}{*}{ Exchange rate } & $-6.30 \mathrm{e}-05^{* *}$ & $-8.25 \mathrm{e}-05^{* *}$ & $-6.37 \mathrm{e}-05$ & $-5.59 \mathrm{e}-05^{*}$ & $-8.04 \mathrm{e}-05^{* *}$ & $-6.23 \mathrm{e}-05$ \\
\hline & $(3.02 \mathrm{e}-05)$ & $(3.56 \mathrm{e}-05)$ & $(3.97 \mathrm{e}-05)$ & $(3.03 \mathrm{e}-05)$ & $(3.56 \mathrm{e}-05)$ & $(3.96 \mathrm{e}-05)$ \\
\hline \multirow[t]{2}{*}{ Tariffs } & & -0.00274 & $0.0387^{* *}$ & & -0.00259 & $0.0524^{* * *}$ \\
\hline & & $(0.0105)$ & $(0.0164)$ & & $(0.0105)$ & $(0.0166)$ \\
\hline \multirow[t]{2}{*}{ Non-tariff trade barriers } & & $-0.0242^{* *}$ & $-0.0591^{* * *}$ & & $0.0330^{* *}$ & 0.00569 \\
\hline & & $(0.0122)$ & $(0.0175)$ & & $(0.0140)$ & $(0.0199)$ \\
\hline \multirow[t]{2}{*}{ Tax compliance } & & $0.0566^{* * *}$ & $0.0488^{* * *}$ & & $0.0421^{* * *}$ & $0.0431^{* * *}$ \\
\hline & & $(0.00951)$ & $(0.0109)$ & & $(0.00956)$ & $(0.0110)$ \\
\hline \multirow[t]{2}{*}{ Starting a business } & & & $0.00247^{*}$ & & & $0.00463^{* * *}$ \\
\hline & & & $(0.00137)$ & & & $(0.00146)$ \\
\hline \multirow[t]{2}{*}{ Investment Treaties } & $0.147^{* * *}$ & $0.116^{* * *}$ & $0.0887^{* *}$ & $0.119^{* * *}$ & $0.124^{* * *}$ & $0.123^{* * *}$ \\
\hline & $(0.0346)$ & $(0.0343)$ & $(0.0387)$ & $(0.0394)$ & $(0.0387)$ & $(0.0435)$ \\
\hline \multirow[t]{2}{*}{ Constant } & $0.527^{* * *}$ & 0.0469 & $2.192^{* * *}$ & $-2.455^{* * *}$ & $-3.742^{* * *}$ & $-3.080 * * *$ \\
\hline & $(0.170)$ & $(0.239)$ & $(0.408)$ & $(0.514)$ & $(0.638)$ & $(0.831)$ \\
\hline Observations & 30,408 & 27,352 & 20,070 & 30,408 & 27,352 & 20,070 \\
\hline R-squared & 0.002 & 0.004 & 0.010 & 0.010 & 0.011 & 0.016 \\
\hline Pair-id FE & YES & YES & YES & YES & YES & YES \\
\hline Number of pair-id & 4,027 & 3,787 & 3,025 & 4,027 & 3,787 & 3,025 \\
\hline Year FE & NO & NO & NO & YES & YES & YES \\
\hline Rho & 0.188 & 0.213 & 0.300 & 0.242 & 0.307 & 0.260 \\
\hline
\end{tabular}

Notes: Regressions include controls for GDP per capita for both Destinations and Origins. Other usual gravity controls are dropped with pair-id fixed effects.

Table 10: Economic Determinants - Gravity Model with Fixed Effects 


\begin{tabular}{|c|c|c|c|c|}
\hline \multirow{3}{*}{$\begin{array}{l}\text { VARIABLES } \\
\text { Political Stability }\end{array}$} & \multirow{2}{*}{\multicolumn{4}{|c|}{$\begin{array}{cc}(2) & (3) \\
\text { FDI inward stocks }(\log )\end{array}$}} \\
\hline & & & & \\
\hline & $\begin{array}{c}-0.317^{* * *} \\
(0.0401)\end{array}$ & $\begin{array}{c}-0.342^{* * *} \\
(0.0513)\end{array}$ & $\begin{array}{c}-0.379^{* * *} \\
(0.0452)\end{array}$ & $\begin{array}{c}-0.316^{* * *} \\
(0.0443)\end{array}$ \\
\hline Labor market regulations & $\begin{array}{l}0.213^{* * *} \\
(0.0338)\end{array}$ & $\begin{array}{c}0.174^{* * *} \\
(0.0317)\end{array}$ & $\begin{array}{l}0.196^{* * *} \\
(0.0310)\end{array}$ & $\begin{array}{c}0.176^{* * *} \\
(0.0314)\end{array}$ \\
\hline Economic Freedom Summary Index & $\begin{array}{l}0.385^{* * *} \\
(0.0891)\end{array}$ & & & \\
\hline Protection of property rights & & $\begin{array}{c}0.343^{* * *} \\
(0.0817)\end{array}$ & & \\
\hline Impartial courts & & & $\begin{array}{c}0.381^{* * * *} \\
(0.0608)\end{array}$ & \\
\hline Corruption & & & & $\begin{array}{l}-0.0667^{*} \\
(0.0394)\end{array}$ \\
\hline Constant & $\begin{array}{c}-1.969^{* *} \\
(0.932)\end{array}$ & $\begin{array}{l}-0.147 \\
(0.547)\end{array}$ & $\begin{array}{c}0.207 \\
(0.556)\end{array}$ & $\begin{array}{l}1.457^{* *} \\
(0.634)\end{array}$ \\
\hline Observations & 1,434 & 1,432 & 1,434 & 1,434 \\
\hline R-squared & 0.543 & 0.542 & 0.546 & 0.535 \\
\hline Adjusted R-squared & 0.539 & 0.538 & 0.542 & 0.531 \\
\hline Economic Determinants & YES & YES & YES & YES \\
\hline
\end{tabular}

Table 11: Institutional Determinants 


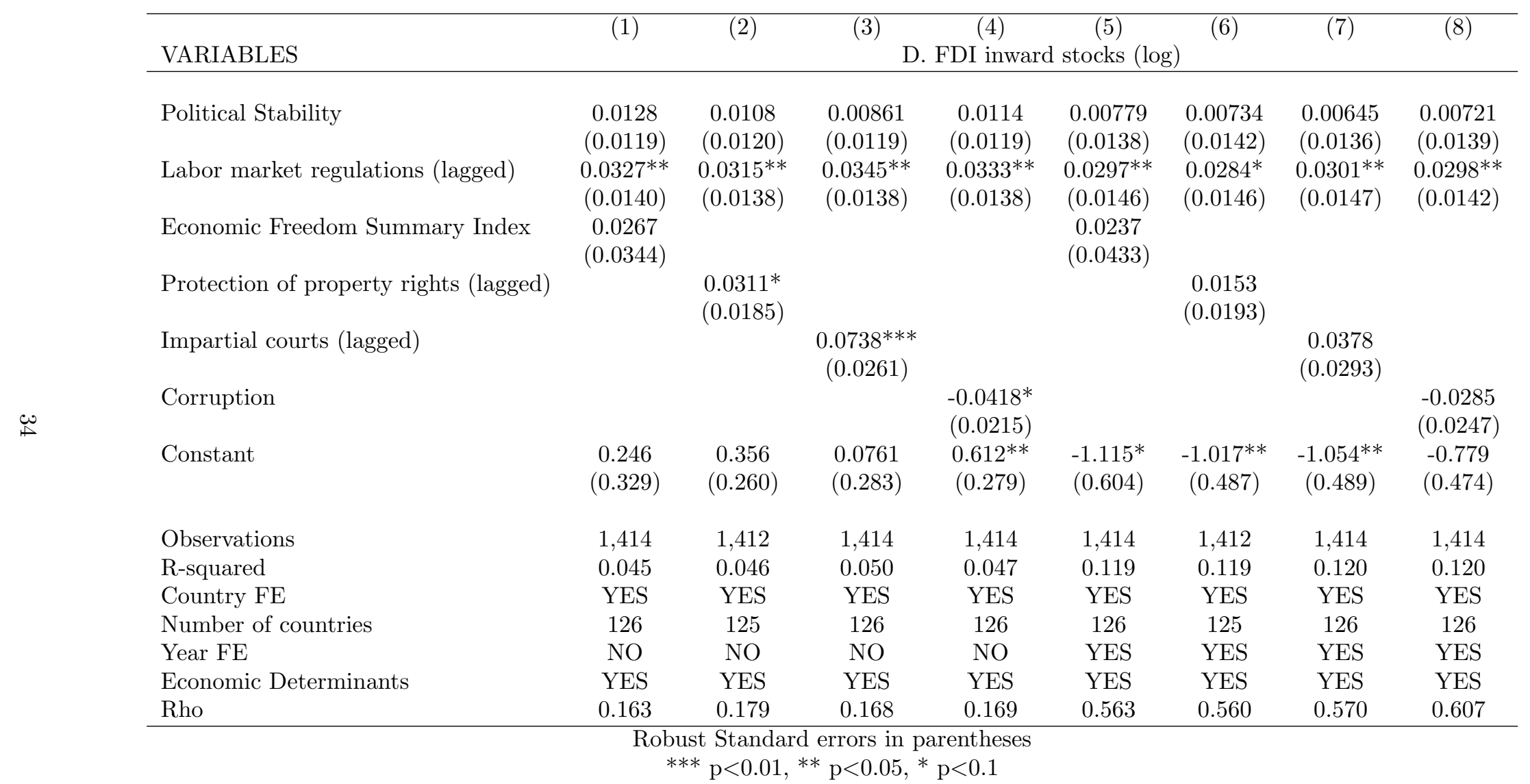

Table 12: Institutional Determinants with Fixed Effects 


\begin{tabular}{|c|c|c|c|c|}
\hline \multirow{3}{*}{$\begin{array}{l}\text { VARIABLES } \\
\text { Distance }\end{array}$} & (1) & $(2)$ & $(3)$ & (4) \\
\hline & \multicolumn{4}{|c|}{ FDI inward stocks (log) } \\
\hline & $\begin{array}{c}-0.606^{* * *} \\
(0.0223)\end{array}$ & $\begin{array}{c}-0.597^{* * *} \\
(0.0221)\end{array}$ & $\begin{array}{c}-0.632 * * * \\
(0.0220)\end{array}$ & $\begin{array}{c}-0.622^{* * *} \\
(0.0220)\end{array}$ \\
\hline GDP of Destination (log) & $0.880^{* * *}$ & $0.872^{* * *}$ & $0.828^{* * *}$ & $0.865^{* * *}$ \\
\hline & $(0.0174)$ & $(0.0176)$ & $(0.0179)$ & $(0.0175)$ \\
\hline GDP of Origin $(\log )$ & $0.401^{* * *}$ & $0.399 * * *$ & $0.396^{* * *}$ & $0.394^{* * *}$ \\
\hline & $(0.00870)$ & $(0.00868)$ & $(0.00866)$ & $(0.00869)$ \\
\hline GDP per capita - Destination & $\begin{array}{c}-0.607^{* * *} \\
(0.0273)\end{array}$ & $\begin{array}{c}-0.631^{* * *} \\
(0.0282)\end{array}$ & $\begin{array}{c}-0.732^{* * *} \\
(0.0282)\end{array}$ & $\begin{array}{c}-0.755^{* * *} \\
(0.0290)\end{array}$ \\
\hline GDP per capita - Origin & $\begin{array}{c}0.673^{* * *} \\
(0.0129)\end{array}$ & $\begin{array}{c}0.671^{* * *} \\
(0.0128)\end{array}$ & $\begin{array}{c}0.677^{* * *} \\
(0.0128)\end{array}$ & $\begin{array}{c}0.673^{* * *} \\
(0.0128)\end{array}$ \\
\hline Religious Proximity & $\begin{array}{c}0.287^{* * *} * \\
(0.0673)\end{array}$ & $\begin{array}{c}0.357 * * * \\
(0.0673)\end{array}$ & $\begin{array}{c}0.492^{* * *} \\
(0.0668)\end{array}$ & $\begin{array}{c}0.402^{* * *} \\
(0.0666)\end{array}$ \\
\hline Regional Trade Agreement & $\begin{array}{c}0.448^{* * *} \\
(0.0452)\end{array}$ & $\begin{array}{c}0.417^{* * *} \\
(0.0453)\end{array}$ & $\begin{array}{c}0.356^{* * *} \\
(0.0451)\end{array}$ & $\begin{array}{c}0.377^{* * *} \\
(0.0451)\end{array}$ \\
\hline Common Currency & $\begin{array}{c}0.00264 \\
(0.263)\end{array}$ & $\begin{array}{c}-0.0398 \\
(0.258)\end{array}$ & $\begin{array}{l}-0.156 \\
(0.260)\end{array}$ & $\begin{array}{l}-0.102 \\
(0.261)\end{array}$ \\
\hline Common language & $\begin{array}{c}1.523^{* * *} \\
(0.0512)\end{array}$ & $\begin{array}{c}1.522^{* * *} \\
(0.0514)\end{array}$ & $\begin{array}{c}1.427 * * * \\
(0.0512)\end{array}$ & $\begin{array}{c}1.457^{* * *} \\
(0.0510)\end{array}$ \\
\hline Political Stability & $\begin{array}{c}0.159^{* * *} \\
(0.0165)\end{array}$ & $\begin{array}{c}0.132^{* * *} \\
(0.0182)\end{array}$ & $\begin{array}{c}0.0332^{*} \\
(0.0189)\end{array}$ & $\begin{array}{c}0.0568^{* * *} * \\
(0.0182)\end{array}$ \\
\hline Labor market regulations & $\begin{array}{c}-0.0366^{* *} \\
(0.0165)\end{array}$ & $\begin{array}{c}-0.0724^{* * *} \\
(0.0160)\end{array}$ & $\begin{array}{c}-0.0476^{* * *} \\
(0.0161)\end{array}$ & $\begin{array}{c}-0.0536^{* * *} \\
(0.0161)\end{array}$ \\
\hline Economic Freedom Summary Index & $\begin{array}{c}0.290^{* * *} \\
(0.0389)\end{array}$ & & & \\
\hline Protection of property rights & & $\begin{array}{c}0.230^{* * *} \\
(0.0353)\end{array}$ & & \\
\hline Impartial courts & & & $\begin{array}{c}0.533^{* * *} \\
(0.0311)\end{array}$ & \\
\hline Corruption & & & & $\begin{array}{c}-0.297^{* * *} \\
(0.0188)\end{array}$ \\
\hline Investment Treaties & $\begin{array}{c}-0.0192 \\
(0.0357)\end{array}$ & $\begin{array}{c}-0.00933 \\
(0.0358)\end{array}$ & $\begin{array}{c}0.0182 \\
(0.0355)\end{array}$ & $\begin{array}{c}0.0379 \\
(0.0357)\end{array}$ \\
\hline Constant & $\begin{array}{c}-29.65^{* * *} \\
(0.488)\end{array}$ & $\begin{array}{c}-28.14^{* * *} \\
(0.439)\end{array}$ & $\begin{array}{c}-26.89^{* * *} \\
(0.445)\end{array}$ & $\begin{array}{c}-23.71^{* * *} \\
(0.524)\end{array}$ \\
\hline Observations & 21,001 & 21,001 & 21,001 & 21,001 \\
\hline R-squared & 0.421 & 0.421 & 0.428 & 0.427 \\
\hline Adjusted R-squared & 0.421 & 0.421 & 0.428 & 0.426 \\
\hline Economic Determinants & YES & YES & YES & YES \\
\hline
\end{tabular}

Table 13: Institutional Determinants - Gravity Model 


\begin{tabular}{|c|c|c|c|c|c|c|c|c|}
\hline \multirow[b]{2}{*}{ VARIABLES } & $(1)$ & $(2)$ & $(3)$ & $(4)$ & $(5)$ & (6) & (7) & $(8)$ \\
\hline & \multicolumn{8}{|c|}{ D. FDI inward stocks (log) } \\
\hline Political Stability & $\begin{array}{l}0.00842 \\
(0.0233)\end{array}$ & $\begin{array}{c}-0.00557 \\
(0.0235)\end{array}$ & $\begin{array}{c}0.00184 \\
(0.0238)\end{array}$ & $\begin{array}{c}0.0160 \\
(0.0235)\end{array}$ & $\begin{array}{r}-0.00206 \\
(0.0242)\end{array}$ & $\begin{array}{c}-0.00235 \\
(0.0244)\end{array}$ & $\begin{array}{c}-0.00116 \\
(0.0247)\end{array}$ & $\begin{array}{l}0.00381 \\
(0.0247)\end{array}$ \\
\hline Labor market regulations (lagged) & $\begin{array}{c}0.0489^{* *} \\
(0.0196)\end{array}$ & $\begin{array}{c}0.0658^{* * *} \\
(0.0188)\end{array}$ & $\begin{array}{c}0.0578^{* * *} \\
(0.0194)\end{array}$ & $\begin{array}{c}0.0435^{* *} \\
(0.0188)\end{array}$ & $\begin{array}{c}0.0438^{* *} \\
(0.0207)\end{array}$ & $\begin{array}{c}0.0627^{* * *} \\
(0.0206)\end{array}$ & $\begin{array}{c}0.0435^{* *} \\
(0.0204)\end{array}$ & $\begin{array}{c}0.0283 \\
(0.0194)\end{array}$ \\
\hline Economic Freedom Summary Index & $\begin{array}{c}0.0638 \\
(0.0550)\end{array}$ & & & & $\begin{array}{c}0.0276 \\
(0.0568)\end{array}$ & & & \\
\hline Protection of property rights (lagged) & & $\begin{array}{c}0.200^{* * *} \\
(0.0300)\end{array}$ & & & & $\begin{array}{c}0.166^{* * *} \\
(0.0447)\end{array}$ & & \\
\hline Impartial courts (lagged) & & & $\begin{array}{c}0.144^{* * *} \\
(0.0465)\end{array}$ & & & & $\begin{array}{c}0.0171 \\
(0.0491)\end{array}$ & \\
\hline Corruption & & & & $\begin{array}{c}0.0319 \\
(0.0347)\end{array}$ & & & & $\begin{array}{c}0.0244 \\
(0.0342)\end{array}$ \\
\hline Investment Treaties & $\begin{array}{c}0.0842^{* *} \\
(0.0391)\end{array}$ & $\begin{array}{l}0.0656^{*} \\
(0.0393)\end{array}$ & $\begin{array}{c}0.0900^{* *} \\
(0.0392)\end{array}$ & $\begin{array}{c}0.0835^{* *} \\
(0.0390)\end{array}$ & $\begin{array}{c}0.128^{* * *} \\
(0.0438)\end{array}$ & $\begin{array}{c}0.123^{* * *} \\
(0.0438)\end{array}$ & $\begin{array}{c}0.129^{* * *} \\
(0.0438)\end{array}$ & $\begin{array}{c}0.131^{* * *} \\
(0.0438)\end{array}$ \\
\hline Constant & $\begin{array}{l}1.370^{* *} \\
(0.567)\end{array}$ & $\begin{array}{c}1.656^{* * *} \\
(0.469)\end{array}$ & $\begin{array}{c}0.844 \\
(0.519)\end{array}$ & $\begin{array}{c}1.577^{* * *} \\
(0.489)\end{array}$ & $\begin{array}{c}-3.432^{* * *} \\
(0.959)\end{array}$ & $\begin{array}{c}-3.676^{* * *} \\
(0.885)\end{array}$ & $\begin{array}{c}-3.321^{* * *} \\
(0.888)\end{array}$ & $\begin{array}{c}-2.794^{* * *} \\
(0.893)\end{array}$ \\
\hline Observations & 19,864 & 19,864 & 19,864 & 19,864 & 19,864 & 19,864 & 19,864 & 19,864 \\
\hline R-squared & 0.010 & 0.013 & 0.011 & 0.010 & 0.017 & 0.018 & 0.017 & 0.016 \\
\hline Pair-id FE & YES & YES & YES & YES & YES & YES & YES & YES \\
\hline Number of pair-id & 2,948 & 2,948 & 2,948 & 2,948 & 2,948 & 2,948 & 2,948 & 2,948 \\
\hline Year FE & $\mathrm{NO}$ & NO & NO & NO & YES & YES & YES & YES \\
\hline Economic Determinants & YES & YES & YES & YES & YES & YES & YES & YES \\
\hline Rho & 0.300 & 0.321 & 0.275 & 0.323 & 0.261 & 0.268 & 0.261 & 0.252 \\
\hline
\end{tabular}

Notes: Regressions include controls for GDP per capita for both Destinations and Origins. Other usual gravity controls are dropped with pair-id fixed effects.

Table 14: Institutional Determinants - Gravity Model with Fixed Effects 